Д. В. Камінський, А. П. Крищишин, О. П. Єлісєєва, Р. Б. Лесик

Львівський національний медичний університет ім. Данила Галицького

79010, м. Львів-10, вул. Пекарська, 69. E-mail: dr_r_lesyk@org.Iviv.net; dankaminskyy@gmail.com

\title{
Донори $\mathrm{H}_{2} \mathrm{~S}$ у створенні інноваційних лікарських засобів
}

Фундаментальні дослідження виокремили нову групу газоподібних речовин, так званих «газотрансміттерів» $\mathrm{NO}, \mathrm{CO}, \mathrm{H}_{2} \mathrm{~S}$, залучених до процесів регуляції великої кількості метаболічних процесів. Результати таких досліджень дозволили окреслити новий напрямок у медичній/фрармацевтичній хімії - створенні сполук донорів сірководню як потенційних лікарських засобів. У роботі представлені основні досягення в галузі пошуку потенційних донорів $\mathrm{H}_{2} \mathrm{~S}$ : основні етапи метаболізму $\mathrm{H}_{2} \mathrm{~S}$ та його біологічні ефекти; класи сполук, здатні вивільняти сірководень відповідно до природи функціональних сульфуровмісних груп та механізму виділення $\mathrm{H}_{2} \mathrm{~S}$. Окремо охарактеризовано найбільш успішний напрямок - створення так званих «гібридних молекул», що вміщуюють фрагменти відомих лікарських засобів, ковалентно зв'язаних з групами, що в той чи інший спосіб здатні вивільняти сірководень.

Ключові слова: $\mathrm{H}_{2} \mathrm{~S}$ метаболізм; біологічні ефекти $\mathrm{H}_{2} \mathrm{~S}$; сірковмісні групи; донори- $\mathrm{H}_{2} \mathrm{~S}$

D. V. Kaminskyy, A. P. Kryshchyshyn, O. P. Yelisyeyeva, R. B. Lesyk

\section{$\mathrm{H}_{2} \mathrm{~S}$ Donors in creation of innovative drugs}

Fundamental studies have identified a new group of gaseous signaling molecules - the so-called gasotransmitters - NO, CO, and $\mathrm{H}_{2} \mathrm{~S}$, which are involved in the regulation of a large number of metabolic processes. The results of these studies allowed determining a new direction in medicinal/pharmaceutical chemistry - creation of hydrogen sulfide donor compounds as potential drugs. The article presents the main achievements in the search for new $\mathrm{H}_{2} \mathrm{~S}$ donors: the main stages of $\mathrm{H}_{2} \mathrm{~S}$ metabolism and its biological effects; the classes of compounds that can release hydrogen sulfide based on the nature of sulfur-containing functional groups as well as the mechanism of $\mathrm{H}_{2} \mathrm{~S}$ releasing. Additionally, the characteristic of the most successful direction - creation of the so-called hybrid molecules is given. The latter are compounds bearing fragments of the well known drugs covalently bounded with groups being capable to release $\mathrm{H}_{2} \mathrm{~S}$.

Key words: $\mathrm{H}_{2} \mathrm{~S}$; metabolism; biological effects of $\mathrm{H}_{2} \mathrm{~S}$; sulfur-containing groups; $\mathrm{H}_{2} \mathrm{~S}$-donors

\section{Д. В. Каминский, А. П. Крищишин, О. П. Елисеева, Р. Б. Лесык}

Доноры $\mathrm{H}_{2} \mathrm{~S}$ в создании инновационных лекарственных средств

Фундаментальные исследования выделили новую группу газообразных веществ, так называемых «газотрансмиттеров» $\mathrm{NO}, \mathrm{CO}, \mathrm{H}_{2} \mathrm{~S}$, которые вовлечены в процессы регуляции большого количества метаболических процесов. Результаты таких исследований позволили выделить новое направление в медицинской/фармацевтической химии - создание соединений доноров сероводорода как потенциальных лекарственных средств. В работе представлены главные достижения в области поиска новых потенциальных доноров $\mathrm{H}_{2} \mathrm{~S}$ : основные этапы метаболизма $\mathrm{H}_{2} \mathrm{~S}$ и его биологические эффекты; классы соединений способных освобождать сероводород, соответственно природы функциональных серосодержащих групп и механизма выделения $\mathrm{H}_{2} \mathrm{~S}$. Отдельно охарактеризовано наиболее успешное направление - создание так называемых «гибридных молекул», которые содержат фрагменты известных лекарственных средств, ковалентно связанных с группами, которые так или иначе способны к выделению сероводорода.

Ключевые слова: $\mathrm{H}_{2} \mathrm{~S}$; метаболизм; биологические эффекты $\mathrm{H}_{2} \mathrm{~S}$; серосодержащие группы; доноры- $\mathrm{H}_{2} \mathrm{~S}$

Сірководень $\left(\mathrm{H}_{2} \mathrm{~S}\right)$ разом із іншими газоподібними молекулами - монооксидом вуглецю (CO) і монооксидом нітрогену (NO) є однією з важливих внутрішньоклітинних сигнальних молекул, яка в останні роки є об'єктом ряду фундаментальних досліджень [1-3]. $\mathrm{H}_{2} \mathrm{~S}$ бере участь у регуляції різноманітних метаболічних процесів, пов'язаних з регуляцією гомеостазу, імунітету, передачі нервових імпульсів тощо. Серед біологічних функцій цієї молекули особливе місце посідає її роль у регуляції серцево-судинної системи, зокрема регуляції тонусу судинної стінки та артеріального тиску.

Дослідження біологічної дії сірководню почалися на початку XX століття і були переважно присвячені вивченню його токсичних властивостей. Розглядання сірководню в якості сигнальної мо- лекули, яка $є$ не тільки токсичним агентом, але і бере участь у регуляції функціональної активності різних клітин, стало можливим лише в кінці XX століття. Одними з перших досліджень у цій області були роботи японських вчених Abe K., i Kimura Н., які в 1996 р. вперше описали можливість синтезу сірководню в тканинах головного мозку і вказали на його здатність регулювати функції клітин [4].

Виявлення таких властивостей $\mathrm{H}_{2} \mathrm{~S}$ стало поштовхом до розвитку нового напрямку в медичній та фармацевтичній хімії, що пов'язано з пошуком принципово нової групи антигіпертензивних препаратів, дія яких грунтується на вивільненні $\mathrm{H}_{2} \mathrm{~S}$, а також інших фармакологічно активних агентів, здатних вивільняти сірководень, так званих до- 
<smiles>NC(CS)C(=O)O</smiles>

цистеїн<smiles>NC(CCS)C(=O)O</smiles>

гомоцистеїн<smiles>NCCS(=O)(=O)O</smiles>

таурин<smiles>NC(CSSCC(N)C(=O)O)C(=O)O</smiles>
цистин<smiles>CSCCC(N)C(=O)O</smiles><smiles>NC1CCSC1=O</smiles>

тіолактон гомоцистеїну<smiles>NC(CCSSCCC(N)C(=O)O)C(=O)O</smiles>

гомоцистин<smiles>NC(CCSSCC(N)C(=O)O)C(=O)O</smiles>

змішаний дисульфід цистеїну та гомоцистеїну<smiles>NC(CCC(=O)NC(CS)C(=O)NCC(=O)O)C(=O)O</smiles>

глутатіон

Рис. 1. Цистеїн, гомоцистеїн, таурин та їхні похідні

норів $\mathrm{H}_{2} \mathrm{~S}$. Інший напрямок досліджень пов'язаний з вивченням метаболічних шляхів утворення та утилізації сірководню та пошуків нових молекул, здатних регулювати ці процеси.

\section{Сірководень - метаболізм та біологічна роль}

Метаболізм сірководню нерозривно пов'язаний з обміном сірковмісних сполук. Основними джерелами сульфуру в людському організмі є сірковмісні амінокислоти - цистеїн, гомоцистеїн, таурин та їхні похідні (рис. 1); деякі вітаміноподібні сполуки, наприклад, ліпоєва кислота і тіоредоксини.

Метаболічні перетворення амінокислот $є$ взаємозалежними та доволі добре описані $[5,6]$. Менша увага приділена окисним перетворенням, наприклад, цистеїну, що включають утворення та залучення сульфітів, пов'язаним із синтезом таурину. Причому на стадії утворення цистеату аніону відбувається також вивільнення молекули сірководню [6, 7] (КФ 1.8.1.3 гіпотаурин дегідрогеназа, КФ 1.13.11.20 цистеїн діоксигеназа, КФ 4.1.1.29 сульфоаланін декарбоксилаза, КФ 4.4.1.10 цистеїн ліаза) (схема 1).
Внутрішньоклітинний синтез сірководню здійснюється в різних клітинах організму. На теперішній час виділяють три основні ферменти, залучені до синтезу сірководню: цистотіонін- $\beta$-синтаза (CBS, КФ 4.2.1.22), цистотіонін- $\gamma$-ліаза (CSE, КФ 4.4.1.1) та 3-меркаптопіруват-сульфуртрансфераза (3-MST, КФ 2.8.1.2) [8] (табл. 1).

Синтез $\mathrm{H}_{2} \mathrm{~S}$ з гомоцистеїну та цистеїну відбувається за участі В6-залежних ензимів (цистатіонін- $\beta$-синтази, цистеїнамінотрансферази) та B6незалежної 3-меркаптопіруват-сульфуртрансферази в корі, гіпокампі, мозочку, стовбурі мозку, церебральних судинах $[9,10]$. Основна реакція утворення $\mathrm{H}_{2} \mathrm{~S}$, як правило, в тканинах мозку - конденсація L-гомоцистеїну з L-цистеїном ( $\beta$-заміщення) за участі CBS $[10,11]$. Встановлено, що десульфуразна активність CBS у тканинах мозку перевищує цистатіонінсинтазну активість. Нещодавно був відкритий ще один шлях утворення $\mathrm{H}_{2} \mathrm{~S}$ на основі цистеїну: L-цистеїн вступає в реакцію трансамінування $3 \alpha$-кетоглутаратом за участі цистеїнамінотрансферази (КФ 2.6.1.3) з утворенням 3-меркаптопірувату, з якого далі вивільняється

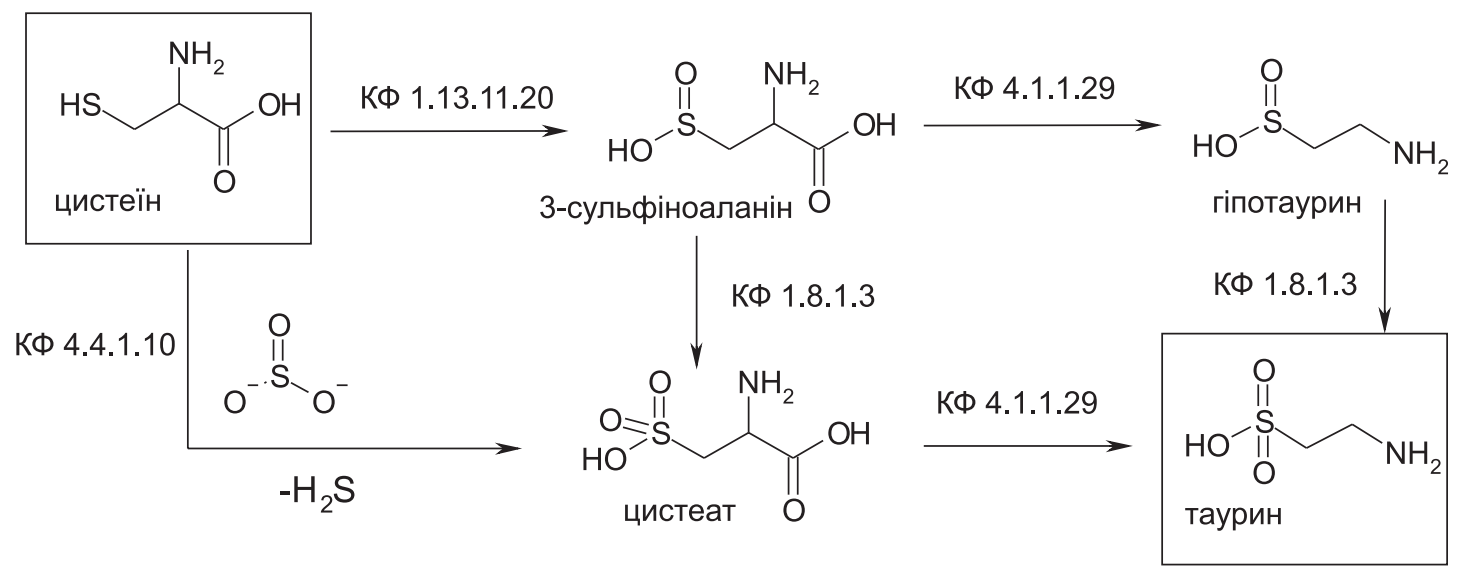


Основні ферментативні реакції утворення сірководню

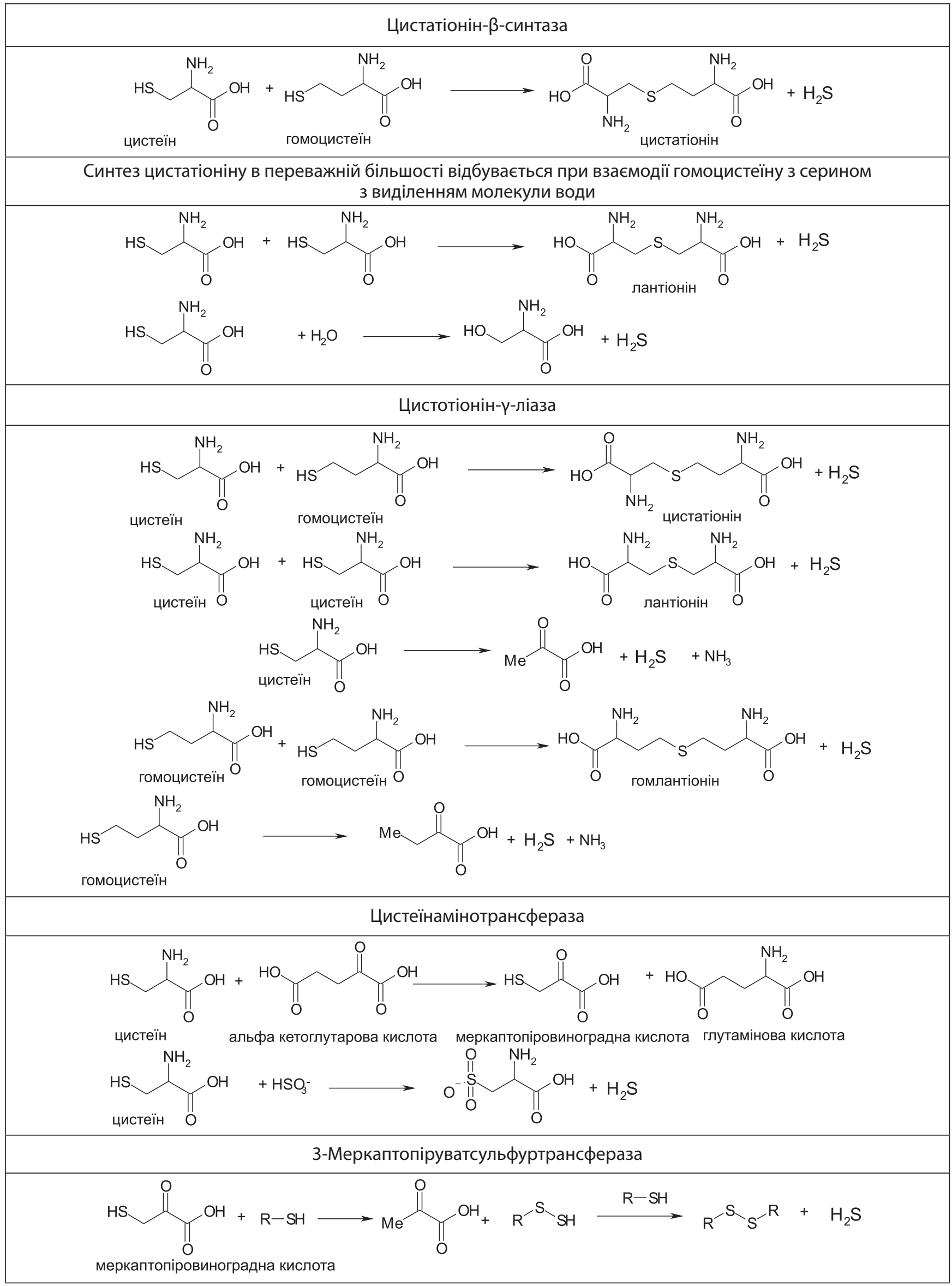




$$
\mathrm{R}^{-} \mathrm{S}_{\mathrm{S}^{-}} \stackrel{\mathrm{GSH}}{\longrightarrow} \mathrm{R}^{-\mathrm{S}}{ }_{\mathrm{S}^{-}} \stackrel{\mathrm{G}}{\longrightarrow}+\mathrm{H}_{2} \mathrm{~S}
$$

Схема 2

$\mathrm{H}_{2} \mathrm{~S}$ за участі 3-MST [12], де в якості кофакторів можуть використовуватися глутатіон, тіоредоксин та дигідроліпоєва кислота. Також продемонстровано роль оксидази D-амінокислот у комбінації з 3-MST у генеруванні $\mathrm{H}_{2} \mathrm{~S}$ з D-цистеїну $[13,14]$.

Крім цього, ряд інших ферментних систем залучено в метаболізм сульфуровмісних сполук та сірководню. Так, наприклад, т-РНК-синтетаза (метіоніл-т-РНК-синтетаза) забезпечує конверсію гомоцистеїну до тіолактону, який швидко гідролізується мітохондріальною тіолактоназою (параоксоназою-1) [15]. Обмін гомоцистеїну та $\mathrm{H}_{2} \mathrm{~S}$ [6] регулюється S-аденозилметіоніном, який є алостеричним інгібітором метилентетрагідрофолатредуктази та метіонінсинтетази і активатором CBS $[10,16,17]$. У свою чергу, активність 3-MST інгібується $\mathrm{Ca}^{2+}$ незалежно від кальмодуліну, тоді як при підвищенні вмісту тіоредоксину та дигідроліпоєвої кислоти в клітинах її активність зростає [18]. Нещодавно також було показано, що 3-MST і роданаза можуть регенерувати $\mathrm{H}_{2} \mathrm{~S}$ з тіосульфату при фізіологічному рівні дигідроліпоєвої кислоти, але не за присутності цистеїну, глутатіону, NADPH або NADH [19]. Певне значення в регуляції обміну гомоцистеїну має вміст у дієті донорів метильних груп - бетаїну та метіоніну, а також вітамінів $\mathrm{B}_{9}, \mathrm{~B}_{12}[17]$.

Значна увага приділяється сульфідним сполукам, які часто розглядають як депо сірководню так званим формам сульфанового сульфуру (sulfane sulfur) [20]. Сполуки, що вміщують сульфановий сульфур, мають унікальну реактивність і виявляють регуляторні ефекти в різних біологічних системах- персульфіди/тіоли, полісульфіди (RSSH або RS(S) $\mathrm{SR})$, гідрополісульфіди (RS(S)nSH) та полісульфани (HS(S)nSH) [21, 22]. Вивільнення сірководню з останніх відбувається при дії тіолів, як правило, глутатіону (GSH) чи цистеїну (схема 2).

Сульфанові сполуки і $\mathrm{H}_{2} \mathrm{~S}$ зазвичай співіснують, і останні роботи свідчать, що сульфанові сполуки, отримані з $\mathrm{H}_{2} \mathrm{~S}$, можуть теж бути активними сигнальними молекулами [23].

На теперішній час виділяють три основні шляхи деградації $\mathrm{H}_{2} \mathrm{~S}$ [24-26]: окиснення в мітохондріальній системі окиснення до тіосульфату, сульфіту або сульфату; цитозольне метилювання до диметилсульфіду; взаємодія з оксигено- та нітровмісними вільнорадикальними частинками; зв'язування з гемоглобіном (формування сульфогемоглобіну) чи іншими гемопротеїнами; утворення ди- та полісульфідів.

Мітохондріальна детоксикація $\mathrm{H}_{2} \mathrm{~S}$ реалізується при дії сульфур-хінон-редуктази (SQR), роданез (Rhod) і сульфур діоксигенази (SDO) та тіосульфат редуктази (TR), що забезпечують окиснення $\mathrm{H}_{2} \mathrm{~S}$ до сульфітів і тіосульфатів. Наступне окиснення при дії сульфітоксидази (SO) приводить до утворення сульфатів як кінцевих продуктів [27]. Оскільки згадані ферменти є кисень-залежними, ефективність деградації сірководню є залежною від $\mathrm{pO}_{2}$ в мітохондріях, що вказує на тісний взаємозв'язок обміну $\mathrm{H}_{2} \mathrm{~S}$ із реакціями за участю активних форм кисню (схема 3).

Метилювання $\mathrm{H}_{2} \mathrm{~S}$ до метилтіолу забезпечується при дії тіол-S-метилтрансферази (TMT).

$\mathrm{H}_{2} \mathrm{~S} \epsilon$ доволі сильним відновником і швидше за все легко реагує з ендогенними окисниками, такими як пероксинітриту аніон (ONOO"), супероксид $\left(\mathrm{O}_{2}{ }^{--}\right)$і перекис водню $\left(\mathrm{H}_{2} \mathrm{O}_{2}\right)$ [21] (схема 4).

$\mathrm{H}_{2} \mathrm{~S}$ може також взаємодіяти з S-нітрозотіолами з утворенням тіонітритної кислоти (HSNO) - найменшого S-нітрозотіолу, метаболіти якого, такі як $\mathrm{NO}^{-}, \mathrm{NO}^{*}$ і NO${ }^{+}$володіють важливими фізіологічними функціями. Неферментативні реакції за учас-

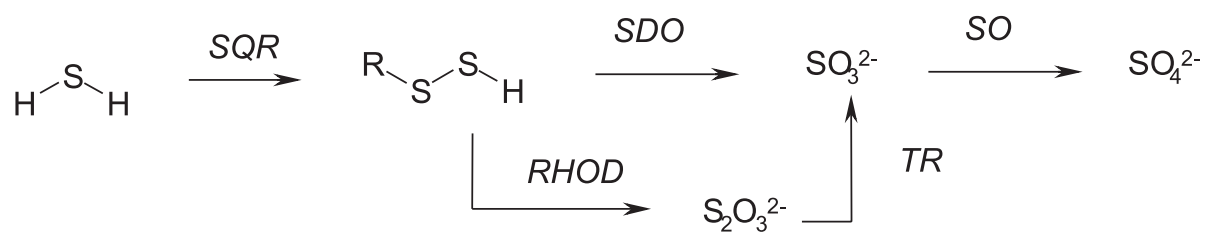

Схема 3

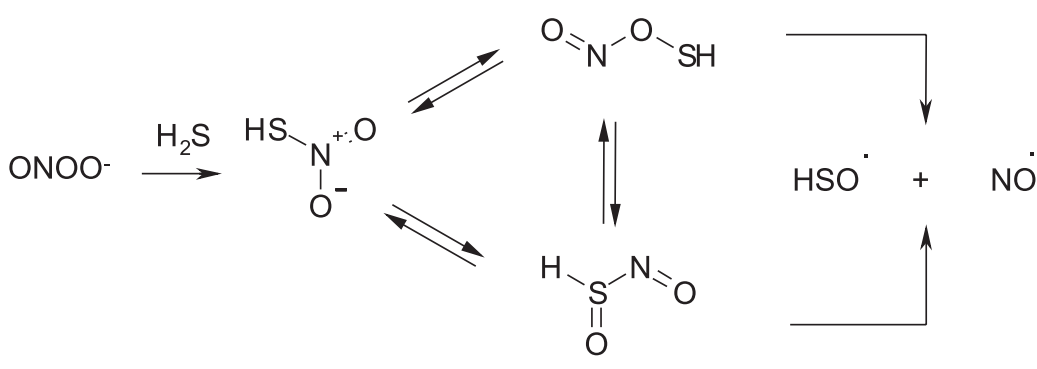

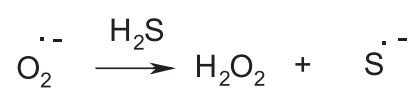

$\mathrm{H}_{2} \mathrm{O}_{2} \stackrel{\mathrm{H}_{2} \mathrm{~S}}{\longrightarrow} \mathrm{H}_{2} \mathrm{O}+\mathrm{HSOH}$ 
тю ROS (радикальних кисневих частинок) i RNS (радикальних частинок нітрогену) ведуть також до утворення окиснених сполук сірки, таких як елементарна сірка і бісульфіт тощо [28].

Оскільки після утворення $\mathrm{H}_{2} \mathrm{~S}$ швидко адсорбується або накопичується у зв'язаному вигляді (так звана кислотно-лабільна сірка - як правило у вигляді дисульфідів, полісульфідів чи персульфідів), концентрація вільного $\mathrm{H}_{2} \mathrm{~S}$ підтримується на базовому рівні. Наприклад, окиснювальна посттрансляційна модифікація тіолових залишків при дії $\mathrm{H}_{2} \mathrm{~S}$ і окисника генерує персульфіди (RSSH), які крім так званого депо гідрогену сульфіду, також виявляють ряд біологічних ефектів [29].

Деякі біологічні ефекти сірководню. Однією з систем, де сірководень відіграє ключову роль як сигнальна молекула, $\epsilon$ серцево-судинна система, зокрема кровоносні судини. Здійснюючи свою регуляторну дію в судинах артеріального русла, він бере активну участь у регуляції артеріального тиску [30]. Так, рівень $\mathrm{H}_{2} \mathrm{~S}$ в крові у хворих на артеріальну гіпертонію $є$ значно зниженим, а призначення інгаляцій сірководню сприяє зниженню артеріального тиску [31]. При проведенні експериментальних досліджень було виявлено, що внутрішньовенне введення розчину сірководню викликало дозозалежне зниження артеріального тиску [1]. Релаксуючу дію сірководню на клітини гладеньких м'язів пов'язують переважно з відкриттям мембранних калієвих каналів, чутливих до концентрації АТФ [32, 33]. Зв'язуючись з сірковмісними групами білків цих каналів, сірководень змінює їх просторову конфігурацію і тим самим сприяє відкриттю каналів [34]. Оскільки на сьогодні $\mathrm{H}_{2} \mathrm{~S}$ вважають основним активатором $\mathrm{K}^{+}{ }_{\text {AтФ }}$ каналів [27], співвідношення $\mathrm{H}_{2} \mathrm{~S} / \mathrm{O}_{2}$, зокрема в мітохондріях, розглядається як один з основних факторів регуляції ритму серця та тонусу автономної нервової системи [35]. У той же час активація АТФ-чутливих калієвих каналів супроводжується інактивацією потенціал-чутливих кальцієвих каналів L-типу, що забезпечують надходження іонів кальцію до клітини. Висока внутрішньоклітинна концентрація $\mathrm{Ca}^{2+} \epsilon$ необхідною умовою розвитку скоротливої відповіді з боку м'язової клітини. Закривання кальцієвих каналів сприяє зниженню концентрації вільного внутрішньоклітинного $\mathrm{Ca}^{2+}$ [31]. Ці процеси в сукупності запускають механізми розслаблення в клітинах гладеньких м'язів, що в кінцевому підсумку приводить до зниження тонусу кровоносних судин і артеріального тиску в цілому.

У ряду досліджень була відзначена цікава особливість сірководню - його здатність у низьких концентраціях викликати скорочення гладких міоцитів [36, 37]. Згідно з однією з гіпотез сірководень зв' язується з оксидом азоту, знижуючи тим самим його концентрацію [38, 39]. Така взаємодія цих двох судинорозслаблючих молекул, як стверджують автори, є причиною збільшення тонусу судин артеріального русла. Також нещодавно було показано, що скоротливий ефект сірководню пов'язаний з активацією мембранного білка $\mathrm{Na}^{+}, \mathrm{K}^{+}, 2 \mathrm{Cl}^{-}-$ котранспортера (NKCC), що забезпечує трансмембранний обмін іонів калію, натрію і хлору. Фізіологічна роль скоротливого ефекту сірководню до кінця не з'ясована: чи є він побічним продуктом якихось внутрішньоклітинних молекулярних реакцій, чи несе на собі функціональне навантаження? У першому випадку збільшення тонусу судин може бути результатом взаємодії сірководню з активними формами кисню, що приводить як до зниження концентрації самого сірководню, так і до утворення продуктів, здатних спричиняти скоротливу відповідь з боку гладком'язових клітин. Другий випадок передбачає специфічну активацію сірководнем механізмів, спрямованих на розвиток короткочасного локального спазму, наприклад, при порушенні цілісності судинної стінки [40].

У фізіологічних умовах $\mathrm{H}_{2} \mathrm{~S}$ збільшує чутливість NMDA-рецепторів нейронів до глутамату, стимулює надходження $\mathrm{Ca}^{2+}$ в астроцити, збільшує синаптичну активність [10]. В умовах патології $\mathrm{H}_{2} \mathrm{~S}$ проявляє нейропротекторні властивості - запобігає розвитку глутамат-індукованого оксидативного стресу, стабілізує функцію мітохондрій та зменшує пошкодження нейронів при експериментальній ішемії-реперфузії, гіпоксії, травмі [10]. $\mathrm{H}_{2} \mathrm{~S}$ виконує важливу роль у функціонуванні ЦНС: проявляє властивості нейротрансміттера, антиоксиданта, антиагреганта та цитопротектора. $\mathrm{H}_{2} \mathrm{~S}$ збільшує синаптичну активність, потенціює ефекти біогенних амінів $[10,11]$, активує цистин-глутаматні антипортери, стимулює надходження цистеїну в мітохондрії, підвищує активність $\gamma$-глутамілцистеїнсинтетази та синтез глутатіону $[9,10] . \mathrm{H}_{2} \mathrm{~S}$ може взаємодіяти з нейроглобіном - гемопротеїном, що запобігає апоптозу нейронів [41, 42].

Показана також роль $\mathrm{H}_{2} \mathrm{~S}$ в регуляції протеїнкіназ, наприклад, таких як р38 мітоген-активована протеїнкіназа, а отже може розглядатись як тригер апоптозу, що підтверджено також протипухлинним ефектом деяких донорів сірководню [13].

3 іншого боку, $\mathrm{H}_{2} \mathrm{~S}$ може виступати в якості скавенджера вільних радикалів та антиоксиданта, що має вирішальне значення в системі охорони здоров'я та профілактики, особливо захворювань серцево-судинної системи [43]. Встановлено, що $\mathrm{H}_{2} \mathrm{~S}$ може реагувати з ROS i RNS, в тому числі супероксид-аніон-радикалом, перекисом водню, пероксинітритом і гіпохлоритом [44, 45].

Показана можливість взаємодії $\mathrm{H}_{2} \mathrm{~S}$ з окисненими тіолами, генеруючи реактивні персульфіди, а також з іонами металів, що входять до складу багатьох ензимів [46]. 
Дослідження останніх років показали, що $\mathrm{H}_{2} \mathrm{~S}$ бере участь у регуляції вісцеральної ноцицепції і соматичній гіпералгезії у мишей. Це спостереження привело до подальшого дослідження ролі активації кальцієвих каналів Т-типу в полегшенні вісцеральної ноцицепції. Оскільки $\mathrm{Zn}^{2+}$ діє як інгібітор Т-типу кальцієвих каналів, особливо ізоформи Cav3.2, $\mathrm{H}_{2} \mathrm{~S}$, який зв'язує іони $\mathrm{Zn}^{2+}$, вважається непрямим активатором кальцієвих каналів Т-типу [26].

Також доведено, що $\mathrm{H}_{2} \mathrm{~S}$ активує TRPA1 (TRPA1 Ankyrin Transient Receptor Potential Channel - один із представників родини TRP-каналів -Transient Receptor Potential Channels - канали транзієнтного рецепторного потенціалу - група рецептор-керованих катіонних каналів, розташованих в основному у плазматичній мембрані) в умовах запалення. Подальше дослідження $\mathrm{H}_{2} \mathrm{~S}$-специфічної активації TRPA1 каналів може надати нові рішення при терапії різних захворювань, наприклад, сечового міхура, викликаних гіперрефлексією, а $\mathrm{H}_{2} \mathrm{~S}, \mathrm{y}$ свою чергу, може впливати на ноцицепцію, що $\epsilon$ результатом функцій TRPA1.

Крім вказаних ефектів, припускається, що зниження рівня сірководню асоційоване з розвитком ряду патологій, зокрема нейродегенеративних [47]. 3 іншого боку, існують дані, що гіперпродукція $\mathrm{H}_{2} \mathrm{~S}$ у тканинах та збільшення вмісту в крові $\epsilon$ патогенетичними чинниками енцефалопатії, наприклад, у щурів з цирозом печінки [48].

Недавні дослідження показують, що $\mathrm{H}_{2} \mathrm{~S}$ може бути використаний в лікуванні запальних захворювань [49] в якості протизапального агента [50]. Ефект пов'язують зі здатністю пригнічувати лейкоцитарну адгезію; збільшенням експресії ICAM-1 (молекул міжклітинної адгезії 1) [51]; пригніченням транскрипції ряду прозапальних генів шляхом регулювання активності NF-кB. Проте також виявлені прозапальний ефект сірководню [52] що реалізується через підвищення концентрації TNF- $\alpha$ (фактор некрозу пухлин) у плазмі, та зниження активності мієлопероксидази [53].

Історично токсична дія $\mathrm{H}_{2} \mathrm{~S}$ пов'язується із пригніченням мітохондріального дихання шляхом впливу на цитохромоксидазу, а саме шляхом взаємодії з іонами міді і/або заліза гему, причому ефект нагадує дію ціаніду. Також $\mathrm{H}_{2} \mathrm{~S}$, зв'язуючись із тривалентним залізом гему мікросомального цитохрому 450 , сприяє розвитку окисного стресу. Таке явище як «анабіоз» (форма гіпометаболізму) $\epsilon$ результатом вище наведеного механізму. Це було вперше виявлено у гризунів, що вдихали $\mathrm{H}_{2} \mathrm{~S}$ [54-56]. Тварини у стані анабіозу нагадували стан сплячки зі зменшеними серцевим викидом, частотою вентиляції і температурою. Такі спостереження можуть бути використані при розробці системи заходів захисту від ургентного ішемічного пошкод- ження тканин міокарда особливо у пацієнтів з інсультом [26].

\section{Донори сірководню}

Неорганічні донори сірководню. Недивлячись на продемонстровані ефекти, використання сірководню (як газу) досліджується мало з огляду на об’єктивні причини [57]. В експериментальній практиці найбільш часто в якості донора сірководню використовуються неорганічні солі ( $\mathrm{NaHS}, \mathrm{Na}_{2} \mathrm{~S}$ ). Однак при розчиненні цих сполук відбувається занадто швидке вивільнення сірководню, що в умоваx in vivo викликає різке падіння артеріального тиску, аж до судинного колапсу. Процес вивільнення сірководню в цьому випадку важко контролюється, що робить $\mathrm{NaHS}$ та $\mathrm{Na}_{2} \mathrm{~S}$ непридатними для використання в терапевтичних цілях [58]. Деякі ефекти використання солей в експериментальних дослідженнях представлені в табл. 2 .

Природні сполуки та їх аналоги як донори сірководню. Природні амінокислоти (N-ацетилцистеїн і L-цистеїн) як попередники синтезу ендогенного $\mathrm{H}_{2} \mathrm{~S} \epsilon$ найбільш привабливими донорами сірководню. Збільшення внутрішньоклітинної концентрації цих молекул викликає додаткову активацію ферментів CSE і CBS i, отже, посилення синтезу $\mathrm{H}_{2} \mathrm{~S}$. Істотною перевагою цих сполук $є$ практично повна відсутність побічних ефектів. Однак труднощі, пов'язані з регулюванням кінцевої концентрації $\mathrm{H}_{2} \mathrm{~S}$, вносять свої обмеження при використанні N-ацетилцистеїну i L-цистеїну як донорів сірководню в клінічній практиці [26].

Крім амінокислот відома велика кількість сірковмісних природних сполук, що міститься в різних видах рослин, тварин, а також грибів і бактерій. Найвідоміші сірковмісні природні сполуки - аліцин і ажоен (різні види часника); овотіол (яйця морського їжака); варацин (морська асцидія); лейнаміцин (Streptomyces), ерготіонеїн і лентіонін [53] (схема 5).

Одними із найдослідженіших природних сполук $\epsilon$ полісульфіди, наприклад, аліцин, який легко розкладається з утворенням різних сульфуровмісних сполук, в тому числі діалілсульфіду, діалілдисульфіду, діалілтрисульфіду [22] (схема 6).

Всі вони розглядаються як донори $\mathrm{H}_{2} \mathrm{~S}$ in vivo, особливо в присутності тіолів. Механізм вивільнення сірководню полягає у перенесенні алілперсульфідного фрагменту, який або може виділяти $\mathrm{H}_{2} \mathrm{~S}$ в результаті відновлення, або при подальшій реакції з тіолами далі залучатись у реакцію з активними сульфгідрильними групами (схема 7).

Загалом три- і тетрасульфіди складають основну частину полісульфідних сполук, але, можливо, що й інші полісульфіди з довшим ланцюгом також присутні в біологічних ізолятах. Проте такі полісульфіди, ймовірно, $є$ більш реакційно-здат- 
Таблиця 2

Ефекти NaHS та $\mathrm{Na}_{2} \mathrm{~S}$ в експерименті (адаптовано за [53])

\begin{tabular}{|c|c|c|}
\hline Експеримент & Ефект & Коментар \\
\hline Щури/вплив овальбуміну, & Протизапальний & $\begin{array}{l}\text { Протизапальна дія, пригнічення ланки патогенезу астми } \\
\text { через } \mathrm{CSE} / \mathrm{H}_{2} \mathrm{~S} \text { шлях }\end{array}$ \\
\hline Гостре ураження легень & Протизапальний & $\begin{array}{l}\text { 3меншення рівня прозапальних цитокінів (IL-6 i IL-8); } \\
\text { збільшення протизапального цитокіну IL-10 }\end{array}$ \\
\hline $\begin{array}{l}\text { Щури/ліпополісахаридіндуковане } \\
\text { запалення }\end{array}$ & Протизапальний & Пригнічення р38 мітоген-активованої протеїнкінази \\
\hline $\begin{array}{l}\text { Щури/«air pouch» модель } \\
\text { запалення }\end{array}$ & Протизапальний & $\begin{array}{l}\text { Пригнічення адгезії лейкоцитів у мезентеріальних } \\
\text { венулах та лейкоцитарної інфільтрації }\end{array}$ \\
\hline $\begin{array}{l}\text { Гостре пошкодження легенів } \\
\text { (вдихання диму) }\end{array}$ & $\begin{array}{l}\text { Протизапальний, } \\
\text { антиоксидантний }\end{array}$ & $\begin{array}{l}\text { 3більшення цитокіну IL-10, зменшення рівня IL-1b та } \\
\text { окиснених білків }\end{array}$ \\
\hline $\begin{array}{l}\text { Гострий артрит, загальна } \\
\text { печінкова ішемія/реперфузія }\end{array}$ & $\begin{array}{l}\text { Протизапальний } \\
\text { Протизапальний/ } \\
\text { антиоксидантний }\end{array}$ & $\begin{array}{l}\text { Потенційне терапевтичне значення в пригніченні } \\
\text { міокардіального і ниркового запалення }\end{array}$ \\
\hline $\begin{array}{l}\text { IFN-gamma-primed лінія U937 } \\
\text { моноцитів людини }\end{array}$ & Прозапальний & $\begin{array}{l}\text { Стимуляція утворення прозапальних цитокінів, частково } \\
\text { через ERK/NF-kB шлях }\end{array}$ \\
\hline $\begin{array}{l}\text { Щури/ліпополісахаридіндуковане } \\
\text { запалення }\end{array}$ & Прозапальний & $\begin{array}{l}\text { Підвищення активності мієлопероксидази і збільшення } \\
\text { рівня TNF-а в плазмі }\end{array}$ \\
\hline
\end{tabular}

ними та можуть частково елімінувати атоми сульфуру за умов виділення, тим самим роблячи їх екстракцію в чистому вигляді проблематичною. Такі сполуки відіграють активну роль у пригніченні синтезу холестерину, агрегації тромбоцитів, а також володіють протизапальною та антиоксидантною дією [59]. Крім лінійних полісульфідів, циклічні полісульфіди також зазвичай є джерелами сульфанового сульфуру. Одним з найбільш відомих представників органічних циклічних полісульфідів є лентіонін, виявлений, наприклад, у грибах шиїтаки (Lentinula edodes) (схема 8).
Для цих сполук також були встановлені вазоактивні властивості - наприклад, діалілдисульфід спричиняє розслаблення кільцевих сегментів аорти щура. Їх терапевтичний потенціал як донорів $\mathrm{H}_{2} \mathrm{~S}$ може реалізовуватися через ферментативні і/або неензиматичні метаболічні шляхи. Окрім того, полісульфідні сполуки є не тільки попередниками $\mathrm{H}_{2} \mathrm{~S}$, але й здатні самостійно спричиняти зміни конформації молекул білків [22, 60].

Крім зазначених відносно простих похідних, виділена велика кількість складних гетероциклічних сполук, що вміщують політіольні групи та<smiles>C=CCSS/C=C/CS(=O)CC=C</smiles>
аліцин

ажоен тіокремонон<smiles>CS(=O)CCCCN=C=S</smiles><smiles>COSCCCCN=C=S</smiles><smiles>C=CCSCC(N)C(=O)O</smiles>

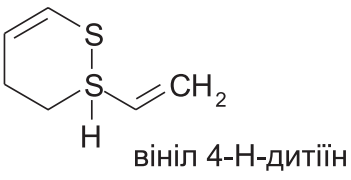<smiles>CS(=O)CCCN=C=S</smiles>

іберин<smiles>C=CCSSCC(N)C(=O)O</smiles><smiles>C[N+](C)(C)C(Cc1c[nH]c(S)n1)C(=O)O</smiles>

ерготіонеїн<smiles>CN(C)C(Cc1c(S)ncn1C)C(=O)O</smiles>

овотіол<smiles>COc1cc(CCN)c2c(c1OC)SSSSS2</smiles>

варацин

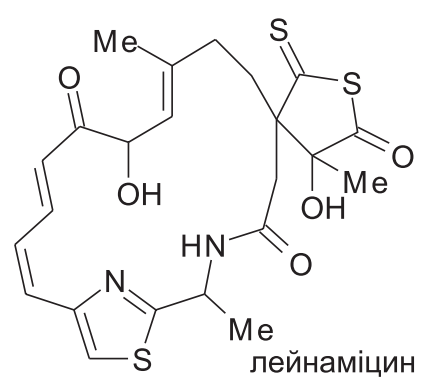




$$
\longrightarrow \text { аліцин }
$$

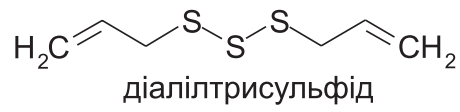

Схема 6

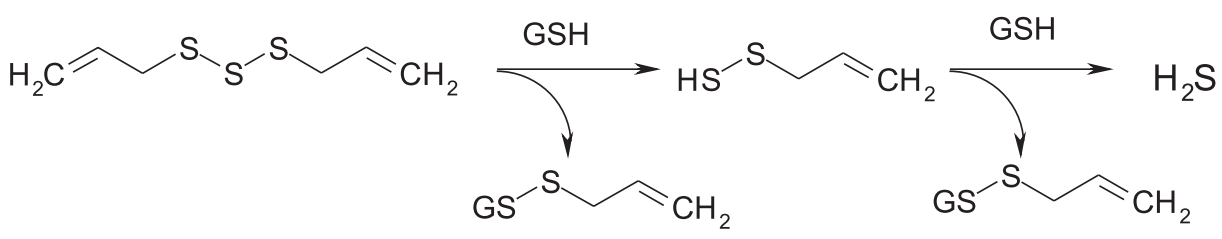

Схема 7

інші сульфуровмісні групи [22]. Найвідомішим серед сполук, що не вміщують полісульфідні зв'язки, є леїнаміцин - 18-членний макролактам, що продукується деякими видами Streptomyces atrolivaceus та виявляє протипухлинні та антимікробні властивості.

Синтетичні сполуки - донори сірководню. Створення молекул, що у водних середовищах здатні вивільняти сірководень, так званих донорів сірководню, $є$ одним з нових напрямків у медичній /фармацевтичній хімії [61]. Можливі молекули-претенденти на роль потенційних лікарських засобів, здатних виділяти сірководень, повинні<smiles>C1SSSSSS1</smiles><smiles>C1SCSSS1</smiles><smiles>C1SCSSCS1</smiles><smiles>COc1cc(C2(c3ncc[nH]3)SSSCC2O)ccc1O</smiles><smiles>COc1cc(CCN)c2c(c1OC)SSSSS2</smiles><smiles>O=C(NCCO)C1SSSCC1O</smiles><smiles>CSC1CSSSC1</smiles><smiles>O=C(O)C1CSSSC1</smiles><smiles>COc1cc(CCN)c2c(c1OC)SSS2</smiles><smiles>COc1c(CCN)c2c(c(OC)c1OC)SSSSS2</smiles>

Схема 8<smiles>CSSSSC</smiles><smiles>Cc1csc(=S)s1</smiles><smiles>Cc1cc(=S)ss1</smiles><smiles>CNC(C)=S</smiles><smiles>COC(C)=S</smiles><smiles>CNSC(C)=O</smiles><smiles>CP(=S)([S-])[S-]</smiles><smiles>CNP(C)(=S)S</smiles><smiles>CNP(=S)(S)OC</smiles><smiles>CSSC(C)=O</smiles><smiles>CCN=C=[Si]</smiles><smiles>O=C1CSC(=S)N1</smiles> 
<smiles>COc1ccc(P2(=S)SP(=S)(c3ccc(OC)cc3)S2)cc1</smiles><smiles>C1COCC[NH+]1</smiles>

Схема 10<smiles>COc1ccc(P(=S)([S-])N2CCOCC2)cc1</smiles><smiles>OCCCCCC(=[Ge])[GeH3]</smiles><smiles>Oc1ccc(P(O)(=S)N2CCOCC2)cc1</smiles><smiles>COc1ccc(P(=O)(O)N2CCOCC2)cc1</smiles>

Схема 11

Фосфорорганічні сполуки. До сполук-донорів сірководню відносяться молекули, що містять так звані активовані P-S зв'язки, як наприклад, у реагенті Лавессона [62]. На основі останнього отримано нову водорозчинну сполуку - донор сірководню 4-морфолініум 4-метоксифеніл(морфоліно) фосфінодитіоат - GYY4137 (схема 10).

На відміну від NaHS GYY4137 вивільняє сірководень поступово, що робить цю молекулу перспективнішою для подальших фармакологічних досліджень [63]. Виділення сірководню відбувається в результаті простого гідролізу та є чутливим до значення $\mathrm{pH}$ (схема 11).

Вумовах in vivo та in vitro встановлено, що GYY4137 володіє судинно-розслаблюючими властивостями і має антигіпертензивну дію, також показана протипухлинна активність цієї сполуки. Проліферація ракових клітин, таких як рак молочної залози (MCF-7), гострий промієлолейкоз (MV4-11), мієломоноцитарний лейкоз (HL-60), була істотно знижена при використанні GYY4137. Тоді як NaHS i ZYJ1122 (структурний аналог GYY4137, де атоми сульфуру замінені на оксиген) були неактивними у такій же концентрації. Вплив GYY4137 на клітини лінії MCF-7 призводив до зупинки клітинного циклу у фазі $\mathrm{G}_{2} / \mathrm{M} \mathrm{i} \mathrm{стимулював} \mathrm{апоптоз.} \mathrm{Факт,}$ що сполука ZYJ1122 (не $\epsilon \mathrm{H}_{2} \mathrm{~S}$-донором) не інгібує ріст пухлинних клітин, дозволяє припустити, що протипухлинний ефект GYY4137 обумовлений власне вивільненням $\mathrm{H}_{2} \mathrm{~S}$ [64].

Нещодавно було розроблено серію фосфордитіоатів - нових $\mathrm{H}_{2} \mathrm{~S}$ донорів шляхом заміни фосфорвуглецевого зв'язку на фосфор-оксигенові зв'язки. Передбачається, що структурні модифікації ядра фосфордитіоатів може привести до зміни функціональних можливостей вивільнення $\mathrm{H}_{2} \mathrm{~S}$ i, в свою чергу, до зміни біологічної активності [66] (схема 12).

Як і у випадку GYY4137, механізм виділення сірководню пов'язаний із гідролітичним розщепленням P-S зв'язків.

Похідні тіокислот та споріднені сполуки. Активними донорами сірководню вважаються похідні тіоамідів, наприклад, NOSH-3 та ATB-346 [66] та АТВ-346 [67], що володіють виразним протипухлинним потенціалом (схема 13).

Деякі з арилтіоамідів також володіють судинорозширюючим ефектом. Виділення сірководню, ймовірно, відбувається внаслідок гідролізу (схема 14).<smiles>S=P1(Nc2ccccc2)SCCS1</smiles><smiles>[Al]OP(=S)([S-])Nc1ccccc1</smiles><smiles>[R]C(C)=[W]</smiles>

Схема 12<smiles>COc1ccc2cc(C(C)C(=O)Oc3ccc(C(N)=S)cc3)ccc2c1</smiles>

ATB-346<smiles>NC(=S)c1ccc(OC(=O)c2ccccc2OC(=O)CCCO[N+](=O)[O-])cc1</smiles>

$\mathrm{NOSH}-3$ 
<smiles>[R]C(=O)Oc1ccc(C(N)=S)cc1</smiles>

Схема 14

Аналогічно роданін і його похідні, що містять дитіокарбаматний фрагмент, який здатен до звільнення $\mathrm{H}_{2} \mathrm{~S}$ при дії кислот чи відновних агентів, можуть розглядатись як потенційні донори $\mathrm{H}_{2} \mathrm{~S}$.

У 2012 р. ряд похідних тіоамінокислот був запропонований як новий клас потенційних донорів сірководню. Такі сполуки, наприклад, тіогліцин та тіовалін у присутності карбонатів перетворюються на відповідні $\mathrm{N}$-карбоксіангідриди аміноксилот, здатні вивільняти сірководень [68] (схема 15).

Хоча для обох - тіогліцину та тіоваліну було доведено здатність вивільняти $\mathrm{H}_{2} \mathrm{~S}$, тіоамінокислоти володіють високою реакційною здатністю. В аеробних умовах вони можуть швидко амідуватися і легко окиснюватися до згаданих дитіопероксіангідридів.

Тіолактивовані донори сірководню. В окрему групу виділені так звані цистеїн активовані (або тіолактивовані) донори сірководню, які, як правило, $є$ стабільними при відсутності цистеїну (чи інших тіолів), а в присутності останнього вивільняють сірководень. Нові, так звані керовані $\mathrm{H}_{2} \mathrm{~S}$ донори також отримані на основі гем-дитіолів, тіогліцину та тіоваліну $[68,69]$. Перші такі спо- луки вміщували N-меркапто фрагмент. Оскільки N-SH група $€$ нестійкою, були запропоновані ї̈ ацильні похідні. Виходячи з відомих даних щодо метаболізму сірковмісних амінокислот, запропонована теорія про те, що сполуки, що вміщують S-N зв'язок, який активується цистеїном, володітимуть терапевтичним потенціалом як донори сірководню. Дана теорія базується на реакційній здатності лабільних нітрозотіолів (S-N), проте потребує подальших експериментальних підтверджень [29]. Пропонований механізм утворення сірководню представлений на схемі 16.

Дисульфідний зв'язок деяких сульфідовмісних сполук NOSH-4 ACS-86, пертіолів, дитіопероксиангідридів також може вступати в реакцію з тіоловими сполуками та відновниками в організмі, тим самим вивільняючи $\mathrm{H}_{2} \mathrm{~S}$ [53] подібно як і у випадку полісульфідів (схема 17).

Подібно до N-SH i S-SH-вмісних донорів дитіопероксіангідриди були запропоновані як інший клас тіолактивованих $\mathrm{H}_{2} \mathrm{~S}$ донорів [70]. Ацилперсульфіди розглядаються як ключові інтермедіати у вивільненні $\mathrm{H}_{2} \mathrm{~S}$. Ймовірно, що ацилперсульфіди взаємодіють 3 тіолами з утворенням $\mathrm{H}_{2} \mathrm{~S}$ i RSSAc. В якості альтернативного механізму пропонується реакція між ацилперсульфідами і тіолами з утворенням нового пертіолу (RS-SH), який потім вступає в реакцію з надлишком тіолів з утворенням $\mathrm{H}_{2} \mathrm{~S}$ (схема 18).

Фотоіндуковані донори $\mathbf{H}_{2} \mathbf{S}$. Нещодавно при розробці тіолнезалежних донорів сірководню ге-

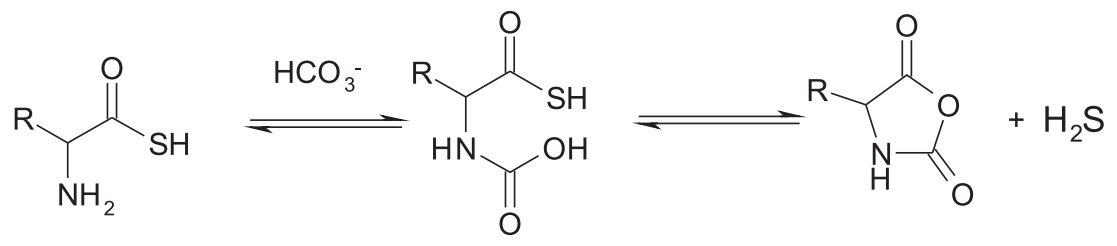

Схема 15<smiles>O=C(NSC(=O)c1ccccc1)c1ccccc1</smiles><smiles>CCOC(=O)CSC(=O)C(N)CSC(=O)C(C)CC</smiles><smiles>O=C(NC(CS)C(=O)O)c1ccccc1</smiles><smiles>NC(CSSCC(N)C(=O)O)C(=O)O</smiles><smiles>NC(CS)C(=O)O</smiles><smiles>NC(CSS)C(=O)O</smiles> 
<smiles>C=CCSSCCC(=O)NC(Cc1ccc(O)c(O)c1)C(=O)OC</smiles>

ACS-86<smiles>O=C(CCCCC1CCSS1)Oc1ccccc1C(=O)OCCCCO[N+](=O)[O-]</smiles>

$\mathrm{NOSH}-4$

Схема 17<smiles>CC(=O)SSC(C)=O</smiles>

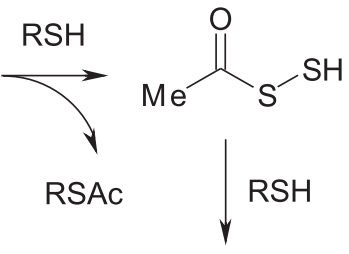<smiles>[SbH]Cc1ccccc1</smiles><smiles>[R]SSC(C)=O</smiles><smiles>[R]SS[Hg]</smiles>

$\mathrm{RSH}$

Схема 18

мінальні-дитіоли були ідентифіковані як нові потенційні базові сполуки [69] для дизайну донорів $\mathrm{H}_{2} \mathrm{~S}$. Гем-дитіольні сполуки $\epsilon$ нестабільними у водних розчинах, a $\mathrm{H}_{2} \mathrm{~S}$ може бути одним із продуктів їх розкладу. Для стабілізації сполук на основі гем-дитіолів була запропонована фотодеградабельна 2-нітробензильна група. При опроміненні утворюється вільний гем-дитіол, який далі піддається гідролізу з утворенням $\mathrm{H}_{2} \mathrm{~S}$ [21] (схема 19).

Група Х. Накагави запропонувала кетопрофенат як фотоімобілізатор для розробки фотолабільних донорів $\mathrm{H}_{2} \mathrm{~S}$ [71]. Такі донори на основі кетопрофенату виділяють $\mathrm{H}_{2} \mathrm{~S}$ при елімінації 2-х еквівалентів 2-пропенілбензофенону та $\mathrm{CO}_{2}$ при опроміненні $(\lambda=300-350$ нм) (схема 20).

Так, на теперішній час відомі два класи фотоіндукованих донорів $\mathrm{H}_{2} \mathrm{~S}$. Слід зазначити, що УФфотоліз біологічних зразків, таких як клітини або тканини може мати і негативні наслідки, наприклад, цитотоксичність. Це в значній мірі обмежує застосування таких донорів $\mathrm{H}_{2} \mathrm{~S}$. Проте ці роботи доводять, що використання, наприклад, гем-дитіолів і кетопрофенат-іммобілізованих тіоетерів $\epsilon$ виправданим, а отримані результати будуть платформою для створення нових тіолнезалежних (не вимагають активації тіолами) донорів сірководню. Наприклад, перспективним напрямком є використання випромінювання ближньої інфрачервоної області (БІЧ). Таке світло може проникати в тканини і звести до мінімуму пошкодження біологічних зразків, і, очевидно, нові БІЧ-активовані донори $\mathrm{H}_{2} \mathrm{~S}$ з'являться найближчим часом [21].

Похідні 1,2-дитіол-3-тіону як донори сірководню. Наступною групою похідних є сполуки, що вміщують 1,2-дитіол-3-тіоновий фрагмент (DTT), як правило, анетіол-1,2-дитіол-3-тіоновий (ADT) чи його метаболіти, наприклад, 5-(4-гідроксифеніл)-3Н-1,2-дитіол-3-тіон (ADT-OH) [72] у поєднанні з іншими молекулярними фрагментами (схема 21).

Вивільнення сірководню відбувається, як і у випадку фосфоровмісних сполуку результаті простого гідролізу [21].

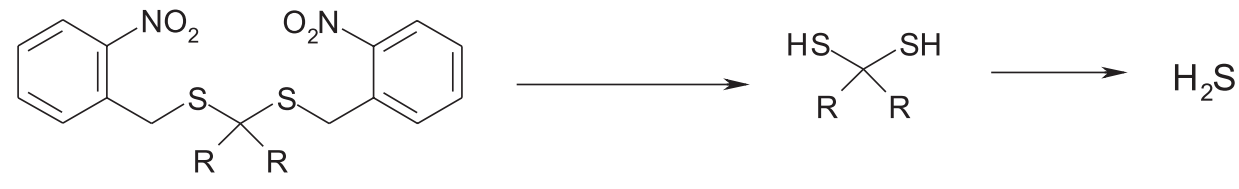

Схема 19<smiles>CSCC(C)(C(=O)O)c1cccc(C(=O)c2ccccc2)c1</smiles><smiles>CCC(C)(C(=O)O)c1cccc(C=O)c1</smiles><smiles>CCc1ccccc1</smiles><smiles>C=C(C)c1cccc(C(=O)c2ccccc2)c1</smiles> 
<smiles></smiles>

DTT<smiles>COc1ccc(-c2cc(=S)ss2)cc1</smiles>

ADT<smiles>Oc1ccc(-c2cc(=S)ss2)cc1</smiles>

\section{A}<smiles>COc1ccc(-c2cc(=S)ss2)cc1</smiles>

ADT-OH<smiles>O=c1cc(-c2ccc(OC34CCCC3CC4)cc2)ss1</smiles>

А - молекулярний фрагмент, як правило, відомих нестероїдних протизапальних лікарських засобів

Схема 21

Молекули гібриди - донори $\mathrm{H}_{2} \mathrm{~S}$. Одним з найуспішніших напрямків розробки «сірководневих» препаратів $\epsilon$ введення функціональних груп, здатних вивільняти сірководень у структуру молекул відомих лікарських засобів [58]. Згаданий анетол дитіолтіон $€$ одним з найбільш використовуваних фрагментів для модифікації структури нестероїдних протизапальних засобів. Роботи в даній сфері ведуться в багатьох лабораторіях, а найбільший доробок відображений в роботах Wallace, J. L. [50, $58,61,67]$. Ряд цих сполук проходить доклінічні випробування: ACS-15 (CTG-Pharma) для терапії артриту, ATB-429 (Antibe) як протизапальний засіб при хворобах кишківника, ATB-284 (Antibe) для терапії синдрому подразненої кишки [53]. Базовою платформою такого підходу є твердження, що основна частина молекули буде зберігати терапевтичну активність (наприклад, протизапальну у випадку нестероїдних протизапальних лікарських засобів), а сірководень, що виділятиметься, забезпечуватиме, з одного боку, зменшення побічних ефектів з боку шлунково-кишкового тракту (цитопротективна дія), а з другого - дозволятиме очікувати інші типи активності, пов'язані з ефектами сірководню, наприклад, протидіабетичний для ADT-аспірину (запобігання збільшенню експресії NOX4 та запобігання підвищенню рівня метилгліоксалю [73]). Так, наприклад, у структурі
NOSH-aspirin/NBS-1120 виділяють фрагмент аспірину, фрагмент, що є донором сірководню, та фрагмент - донор оксиду азоту [66, 74], сполука разом з протизапальним ефектом володіє протипухлинною активністю (схема 22).

Альтернативні донори сірководню можуть бути отримані шляхом введення інших груп, наприклад, сульфідних у структуру нестероїдних протизапальних препаратів. Наприклад, S-диклофенак містить тіонові групи, які відіграють роль джерела сірководню [72]. Аналогічно модифікація лікарських засобів інших терапевчтичних груп активно досліджується в межах такого підходу (схема 23).

Введення сірковмісних груп у молекулу силденафілу призводить до розвитку ефекту, пов'язаного з істотною релаксацією гладких клітин кавернозних тіл [75].

Деякі фармакологічні ефекти донорів сірководню. Фармакологічні ефекти сполук донорів сірководню тісно пов'язані з біологічними ефектами самого сірководню та в більшості випадків імітують їх (табл. 3). Сполуки-гібриди, як правило, володіють активністю основної частини молекули як у випадку модифікованих протизапальних засобів.

Донори $\mathrm{H}_{2} \mathrm{~S}$ зменшують пошкодження мозку в умовах експериментальної ішемії-реперфузії, гіпоксії, травми мозку $[9,10]$. Нещодавно показано,<smiles>Nc1ccc(O)c(C(=O)Oc2ccc(-c3cc(=S)ss3)cc2)c1</smiles>

ATB-429

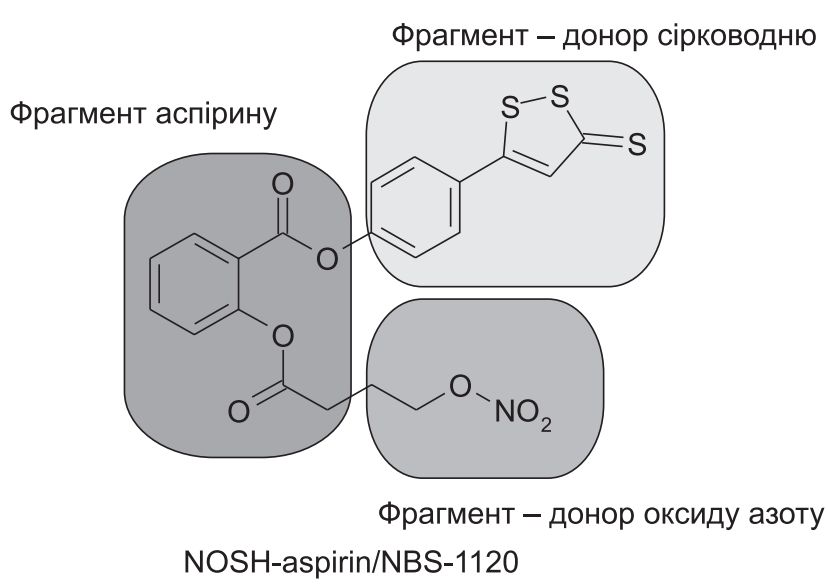

NOSH-aspirin/NBS-1120 
<smiles>CCCc1nn(C)c2c(=O)[nH]c(-c3cc(S(=O)(=O)N4CCN(CC(=O)Oc5ccc(-c6cc(=S)ss6)cc5)CC4)ccc3OCC)nc12</smiles>

ACS-6/S-sildenafil<smiles>O=C(CCC/C=C\C[C@@H]1C(CCC(O)CCc2ccccc2)[C@H](O)C[C@H]1O)Oc1ccc(-c2cc(=S)ss2)cc1</smiles>

ACS-67/S-latanoprost

Схема 23

Таблиця 3

Ефекти донорів сірководню, адаптовано за [21]

\begin{tabular}{|c|c|c|c|}
\hline $\mathrm{H}_{2} \mathrm{~S}$ донор & Структура & $\begin{array}{c}\text { Механізм виділення } \\
\mathrm{H}_{2} \mathrm{~S}\end{array}$ & Репрезентативна активність* \\
\hline 1 & 2 & 3 & 4 \\
\hline $\mathrm{H}_{2} \mathrm{~S}$ (газ) & $\mathrm{H}_{2} \mathrm{~S}$ & & $\begin{array}{l}\text { Індукція анабіозу, } \\
\text { антидіабетична дія, } \\
\text { антигіпертензивна дія }\end{array}$ \\
\hline Неорганічні сульфіди & $\mathrm{NaHS}, \mathrm{Na}_{2} \mathrm{~S}$ & гідроліз & $\begin{array}{l}\text { Зменшення пошкоджень } \\
\text { міокарда, цитопротекція, } \\
\text { антиульцерогенна дія }\end{array}$ \\
\hline $\begin{array}{l}\text { Сульфуровмісні сполуки } \\
\text { часника (Полісульфіди) }\end{array}$ & $\mathrm{R}-\mathrm{S}-\mathrm{Sn}-\mathrm{S}-\mathrm{R}$ & активація тіолами & $\begin{array}{l}\text { Протизапальна, } \\
\text { антиоксидантна, } \\
\text { судинорозширювальна дія }\end{array}$ \\
\hline Реагент Лавессона & & гідроліз & $\begin{array}{l}\text { Протизапальна дія, регуляція } \\
\text { активності іонних каналів }\end{array}$ \\
\hline GYY4137 & & гідроліз & $\begin{array}{l}\text { Протизапальна, судино- } \\
\text { розширювальна, } \\
\text { протипухлинна активність }\end{array}$ \\
\hline Фосфородитіоати & $\mathrm{Ph}-\mathrm{N}^{\prime}$ & гідроліз & $\begin{array}{l}\text { Захист від окисного } \\
\text { пошкодження }\end{array}$ \\
\hline DTT & & гідроліз & Протизапальна, протипухлинна \\
\hline
\end{tabular}


Продовження таблиці 3

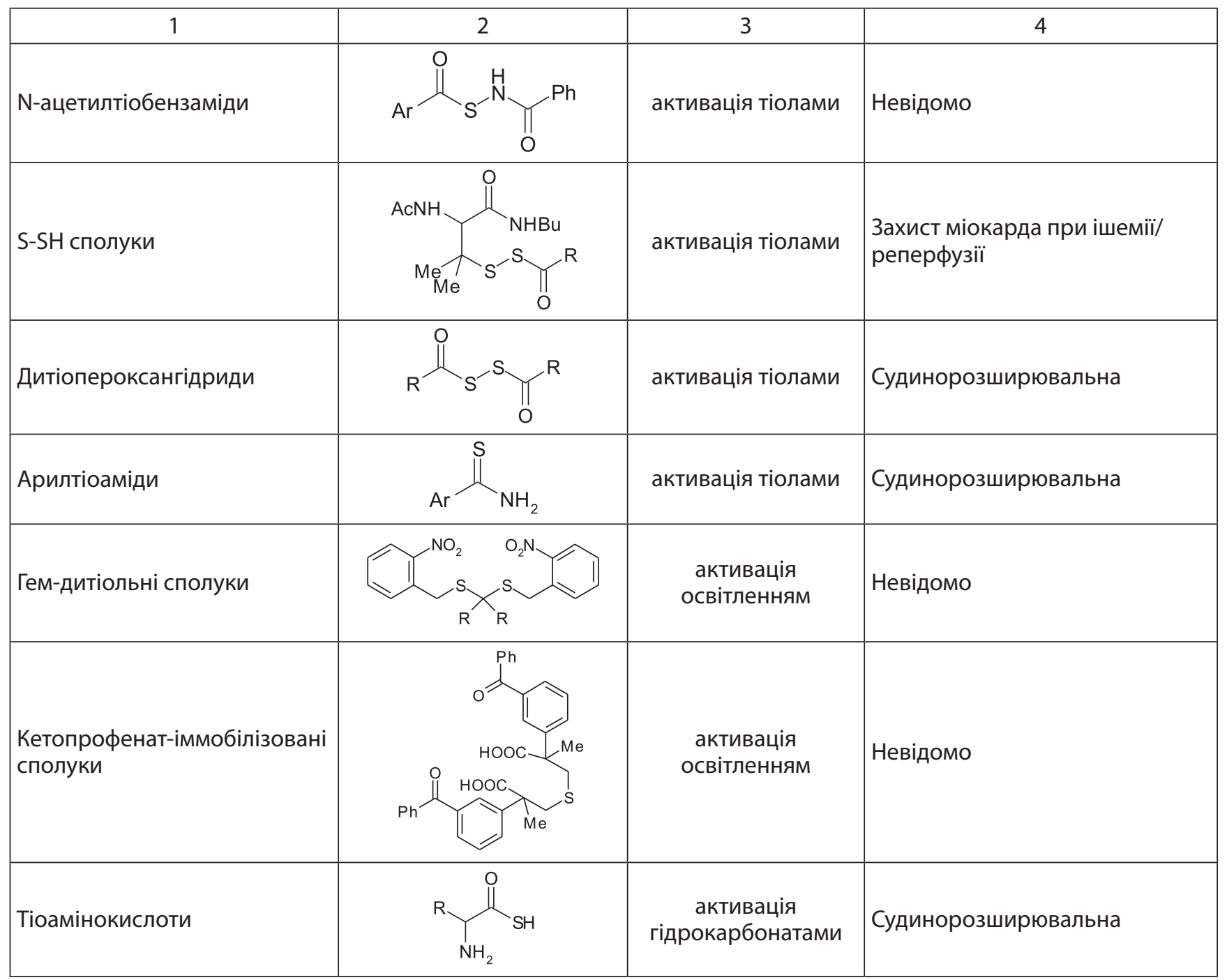

Примітка: * - активність підтверджена в кількох публікаціях.

що донори $\mathrm{H}_{2} \mathrm{~S}$ зменшують нейродегенеративні зміни в мозку мишей $[42,76]$. Ряд сполук досліджується як перспективні протипухлинні агенти, причому протипухлинна дія пов'язується якраз із вивільненням сірководню. Протипухлинна активність часто пов'язується з антиоксидантним чи прооксидантним впливом таких донорів. Так, ерготіонеїн був досліджений як антиоксидант на клітинній лінії (N-18-RE-105). У дослідженні з використанням пероксиду водню і пероксинітриту показано зниження рівня окисного пошкодження, викликаного останніми [77]. Овотіол діє як ефективний скавенджер пероксиду водню та інших кисевих радикалів, причому ефективніше, ніж каталаза. Окиснений овотіол може реагувати з глутатіоном шляхом тіол-дисульфідного обміну, що при подальшій окисно-відновній утилізації окиснених та відновлених форм глутатіону веде до утворення $\mathrm{H}_{2} \mathrm{~S}$ [53]. Проте часто дослідження демонструють відсутність прямих антиоксидантних ефектів [78].
Найбільш досліджуваними є згадані сполукигібриди, які поєднують кілька фармакологічно активних центрів у молекулі. Основні ефекти деяких сполук представлені у табл. 4.

Похідні роданіну як можливі донори $\mathrm{H}_{2} \mathrm{~S}$. Зважаючи на структурну спорідненість та реакційну здатність 4-тіазолідинонів [79], з'являються поодинокі повідомлення [53] про можливість використання 4-тіазолідинонового скафолду (особливо роданінового) в дизайні нових донорів сірководню (схема 24).

Виділені фрагменти відповідають структурі відомих донорів сірководню. Аналіз реакційної здатності зазначених сполук дозволяє стверджувати посилення здатності генерувати виділення сірководню в ряду від роданіну до тіороданіну як в умоваx in vitro, так і in vivo. Попередні дослідження, проведені у співпраці з кафедрою біологічної xiмії Львівського національного медичного університету імені Данила Галицького [80, 81], свідчать про перспективність дослідження похідних тіа- 
Таблиця 4

Ефекти молекул-гібридів донорів $\mathrm{H}_{2} \mathrm{~S}$ (адаптовано за [53])

\begin{tabular}{|c|c|c|c|}
\hline $\mathrm{H}_{2} \mathrm{~S}$ донор & Експеримент & Ефект & Коментар \\
\hline \multirow[t]{2}{*}{ ACS-15 } & $\begin{array}{c}\text { Ліпополісахаридіндуковане } \\
\text { запалення }\end{array}$ & протизапальний & $\begin{array}{c}\text { Протизапальна активність вища в } \\
\text { порівнянні з немодифікованими ЛЗ, значне } \\
\text { зменшення токсичності по відношенню до } \\
\text { гастропатії }\end{array}$ \\
\hline & $\begin{array}{c}\text { Канцероспричинений } \\
\text { остеокласт }\end{array}$ & протираковий & $\begin{array}{c}\text { Інгібування росту клітин раку молочної } \\
\text { залози, забезпечення підтримки } \\
\text { остеокластогенезу, запобігання остеолізу }\end{array}$ \\
\hline \multirow{2}{*}{ ATB-429 } & Модельний коліт & протизапальний & $\begin{array}{c}\text { 3меншення інфільтрацій гранулоцитів, } \\
\text { зменшення експресії прозапальних } \\
\text { цитокінів, посилення активності мелазаміну }\end{array}$ \\
\hline & $\begin{array}{c}\text { Колоректальне здуття, } \\
\text { індуковане постзапальною } \\
\text { гіперчутливістю }\end{array}$ & антиноцицептивний & $\begin{array}{c}\text { Зниження рівня експресії ЦОГ } 2 \text { і мРНК } \\
\text { IL-1b та c-FOS mRNA, гальмування } \\
\text { гіперчутливості і болю }\end{array}$ \\
\hline NBS-1120 & $\begin{array}{c}\text { НТ-29 лінія (рак товстої } \\
\text { кишки) }\end{array}$ & протираковий & $\begin{array}{c}\text { Пригнічення росту ракових клітин, } \\
\text { зменшення об' єму пухлини }\end{array}$ \\
\hline \begin{tabular}{|l|} 
HS-sulindac, \\
HS-ibuprofen, \\
HS-naproxen, \\
HS-aspirin \\
\end{tabular} & $\begin{array}{l}\text { Клітинні лінії різних типів } \\
\text { раку }\end{array}$ & протираковий & $\begin{array}{c}\text { Пригнічення росту ракових клітин, ефект } \\
\text { значно перевищує немодифіковані Л3 }\end{array}$ \\
\hline HS-ASA & $\begin{array}{c}\text { MDA-MB-231 лінія раку } \\
\text { молочної залози }\end{array}$ & $\begin{array}{c}\text { протираковий, } \\
\text { прооксидантний }\end{array}$ & $\begin{array}{c}\text { Регуляція активності NF-kB i TrxR, індукція } \\
\text { ROS, пригнічення росту ракових клітин }\end{array}$ \\
\hline NOSH-1,2 & $\begin{array}{l}\text { Клітинні лінії різних типів } \\
\text { раку } \\
\end{array}$ & протираковий & $\begin{array}{c}\text { Пригнічення росту ракових клітин }\left(\mathrm{IC}^{50} \text { до } 3\right. \\
\mathrm{nM}), \text { низька цитотоксичність }\end{array}$ \\
\hline ACS14/ACS1 & $\begin{array}{l}\text { Глутаматпровоковане } \\
\text { ушкодження RGC-5 }\end{array}$ & $\begin{array}{c}\text { антиоксидантний, } \\
\text { регуляція іонних } \\
\text { каналів } \\
\end{array}$ & $\begin{array}{c}\text { Ефективна нейропротекція; зменшення } \\
\text { проявів окисного стресу, індукція } \\
\text { глутатіону, відкриття } \mathrm{K}^{+} \text {каналів }\end{array}$ \\
\hline $\begin{array}{l}\text { ACS14/ } \\
\text { ADTOH/ACS21 }\end{array}$ & Щури лінії/Sprague-Dawley & $\begin{array}{c}\text { антитромбозний, } \\
\text { зменшення } \\
\text { токсичності }\end{array}$ & $\begin{array}{c}\text { Відновлення слизової оболонки шлунка, } \\
\text { збільшення відношення } \mathrm{H}_{2} \mathrm{~S} / \mathrm{GSH}\end{array}$ \\
\hline ACS14 & Цільна кров & антитромбозний & $\begin{array}{c}\text { Інгібування утворення тромбів у невеликих } \\
\text { артеріолах та артеріях }\end{array}$ \\
\hline
\end{tabular}<smiles>O=C1CSCN1</smiles>

Схема 24

золідинону як донорів сірководню. Так, показано, що 5-(3,5-дитретбутил-4-гідроксибензиліден)-4тіоксо-тіазолідин-2-он володіє зниженою ентеротоксичністю (в порівнянні з відомими протизапальними нестероїдними засобами) як за рахунок ефектів, зумовлених впливом $\mathrm{H}_{2} \mathrm{~S}$, що вивільняється 3 них у травному тракті, так і за рахунок одночасного інгібування циклооксигенази та ліпооксигенази $[80,81]$.

\section{Висновки}

У роботі узагальнені основні метаболічні процеси сірководню, основну увагу зосереджено на<smiles>O=C1CCCCC1=S</smiles>

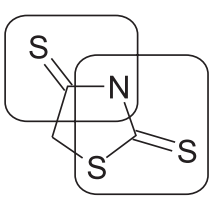

тіороданін

сірковмісних амінокислотах як основних джерелах $\mathrm{H}_{2} \mathrm{~S}$, на шляхах утворення та утилізації сірководню in vivo та ролі $\mathrm{H}_{2} \mathrm{~S}$ як одного з газотрансміттерів. Систематизовані основні групи органічних сполук, що розглядаються як донори сірководню відповідно до хімічної структури функціональних груп, відповідальних за виділення сірководню. Представлені основні можливі механізми вивільнення сірководню донорами $\mathrm{H}_{2} \mathrm{~S}$ в організмі.

Представлені основні фармакологічні ефекти сполук донорів сірководню, виокремлені напрямки, що потребують подальшого вивчення. Пред- 
ставлено найуспішніший напрямок створення сполук донорів сірководню - так званих гібридних молекул чи молекул-химер, які вміщують ковалентно зв'язані фрагменти відомих лікарських засобів, що в той чи інший спосіб здатні вивільняти сірководень. В основі такого підходу лежить твердження, що сполука буде виявляти ефект «материнської» структури, а сірководень дозволить зменшити побічні ефекти, підвищити ефективність і/або забезпечить появу нового типу активності.

\section{Конфлікт інтересів: відсутній.}

\section{Перелік використаних джерел інформації}

1. Lowicka, E. Hydrogen sulfide (H(2)S) - the third gas of interest for pharmacologists / E. Lowicka, J. Beltowski // Pharmacol. Reports. - 2007. Vol. 59, Issue 1. - P. 4-24. Available at: http://if-pan.krakow.pl/pjp/pdf/2007/1_4.pdf

2. Li, L. Actions and interactions of nitric oxide, carbon monoxide and hydrogen sulphide in the cardiovascular system and in inflammation - a tale of three gases! / L. Li, A. Hsu, P. K. Moore // Pharmacol. \& Therapeutics. - 2009. - Vol. 123, Issue 3. - P. 386-400. doi: 10.1016/j.pharmthera.2009.05.005

3. Pryor, W. A. Free radical biology and medicine : it's a gas, man! / W. A. Pryor // AJP : Regulatory, Integrative and Comparative Physiol. - 2006. - Vol. 291, Issue 3. - P. R491-R511. doi: 10.1152/ajpregu.00614.2005

4. Abe, K. The possible role of hydrogen sulfide as an endogenous neuromodulator / K. Abe, H. J. Kimura // Neurosci. - 1996. - Vol. 16, Issue 3. P. 1066-1071. Available at: http://www.jneurosci.org/content/jneuro/16/3/1066.full.pdf

5. Brosnan, J. T.The sulfur-containing amino acids : an overview / J. T. Brosnan, M. E. Brosnan // J. Nutrit. - 2006. - Vol. 136, Issue 6. - P. 1636-1640. Available at : http://jn.nutrition.org/content/136/6/1636S.full.pdf+html

6. Impaired homocysteine metabolism and atherothrombotic disease / P. Durand, M. Prost, N. Loreau et al. // D. Lab. Invest. - 2001. - Vol. 81, Issue 5. P. 645-672. Available at : http://www.nature.com/labinvest/journal/v81/n5/pdf/3780275a.pdf

7. Hayes, K. C. Taurine in metabolism / K. C. Hayer, J. A. Sturman // Ann. Rev. Nutr. - 1981. - Vol. 1. - P. 401-425.

8. Kabil, O. Enzymology of H2S Biogenesis, Decay and Signaling / O. Kabil, R. Banerjee // Antiox. Redox. Signal. - 2014. - Vol. 20, Issue 5. - P. 770-782. doi: 10.1089 /ars.2013.5339

9. Kimura, H. Hydrogen sulfide : its production and functions / H. Kimura // Exp. Physiol. - 2011. - Vol. 96, Issue 9. - P. 833-835. doi: 10.1113/ expphysiol.2011.057455

10. Kimura, H. Physiological role of hydrogen sulfide and polysulfide in the central nervous system / H. Kimura // Neurochem. Int. - 2013. - Vol. 63, Issue 5. - P.492-497. doi: 10.1016/j.neuint.2013.09.003

11. Dynamic Change of Hydrogen Sulfide After Traumatic Brain Injury and its Effect in Mice / M. Zhang, H. Shan, T. Wang et al. // Neurochem. Res. 2013. - Vol. 38, Issue 4. - P.714-725.doi: 10.1007/s11064-013-0969-4

12. Vascular Endothelium Expresses 3-Mercaptopyruvate Sulfurtransferase and Produces Hydrogen Sulfide / N. Shibuya, Y. Mikami, Y. Kimura et al // J. Biochem. - 2009. - 146, Issue 5. - P. 623-626. doi: 10.1093/jb/mvp111

13. Wang, R. Physiological Implications of Hydrogen Sulfide : A Whiff Exploration That Blossomed / R. Wang // Physiol. Rev. - 2012. - Vol. 92, Issue 2. - P.791-896. doi: 10.1152/physrev.00017.2011

14. A novel pathway for the production of hydrogen sulfide from D-cysteine in mammalian cells / N. Shibuya, S. Koike, M. Tanaka et al. // Nature Commun. - 2013. - Vol. 4. - 1366 p. doi: $10.1038 /$ ncomms2371

15. Jakubowski, H. Synthesis of homocysteine thiolactone by methionyl-tRNA synthetase in cultured mammalian cells / H. Jakubowski, E. Goldman // FEBS Lett. - 1993. - Vol. 317, Issue 3. - P. 237-240. doi: 10.1016/0014-5793(93)81283-6

16. Eto, K. The production of hydrogen sulfide is regulated by testosterone and S-adenosyl-l-methionine in mouse brain / K. Eto, H. Kimura // J. Neurochem. -2002. - Vol. 83, Issue 1. - P.80-86. doi: 10.1046/j.1471-4159.2002.01097.x

17. Obeid, R. Mechanisms of homocysteine neurotoxicity in neurodegenerative diseases with special reference to dementia / R. Obeid, W. Herrmann // FEBS Lett. - 2006. - Vol. 580, Issue 13. - P. 2994-3005. doi: 10.1016/j.febslet.2006.04.088

18. Kimura, H. Hydrogen Sulfide Is a Signaling Molecule and a Cytoprotectant / H. Kimura, Y. Kimura, N. Shibuya // Antioxid. Redox. Signal. - 2012. - Vol. 17, Issue 1. - P.45-57. doi: 10.1089/ars.2011.4345

19. Thioredoxin and dihydrolipoic acid are required for 3-mercaptopyruvate sulfurtransferase to produce hydrogen sulfide / Y. Mikami, N. Shibuya, Y. Kimura et al. // Biochem. J. - 2011. - Vol. 439, Issue 3. - P. 479-485. doi: 10.1042/BJ20110841

20. Qian, L. Chemical foundations of hydrogen sulfide biology / L. Qian, J. R. Lancaster // Nitric Oxide. - 2013. - Vol. 35. - P. 21-34. doi: 10.1016/j. niox.2013.07.001

21. Zhao, Y. Hydrogen sulfide (H2S) releasing agents : chemistry and biological applications / Y. Zhao, T. D. Biggs, M. Xian // Chem. Comm. - 2014. Vol. 50, Issue 8. - P. 11788-11805. doi: 10.1039/C4CC00968A

22. Natural Products Containing Hydrogen Sulfide Releasing Moieties / M. D. Pluth, T. S. Bailey, M. D. Hammers et al. // Synlett. - 2015. - Vol. 26, Issue 19. - P. 2633-2643. doi: 10.1055/s-0035-1560638

23. Polysulfides are possible H2S-derived signaling molecules in rat brain / Y. Kimura, Y. Mikami, K. Osumi et al. // FASEB J. - 2013. - Vol. 27, Issue 6. P. 2451-2457. doi: 10.1096/fj.12-226415

24. Kimura, H. Hydrogen sulfide : its production, release and functions / H. Kimura // Amino Acids. - 2011. - Vol. 41, Issue 1. - P. 113-121. doi: $10.1007 / \mathrm{s} 00726-010-0510-\mathrm{x}$

25. Hughes, M. N. Making and working with hydrogen sulfide / M. N. Hughes, M. N. Centelles, K. P. Moore // Free Radic. Biol. Med. - 2009. - Vol. 47, Issue 10. - P. 1346-1353. doi: 10.1016/j.freeradbiomed.2009.09.018

26. Guo, W. Hydrogen sulfide and translational medicine / W. Guo, Z. Y. Cheng, Y. Z. Zhu // Acta Pharmacol. Sinica. - 2013. - Vol. 34, Issue 10. P. 1284-1291. doi: 10.1038/aps.2013.127

27. Kashfi, K. Biology and therapeutic potential of hydrogen sulfide and hydrogen sulfide-releasing chimeras / K. Kashfi, K. R. Olson // Biochem. Pharmacol. 2013. - Vol. 85, Issue 5. - P. 689-703. doi: 10.1016/j.bcp.2012.10.019

28. Reactivity of hydrogen sulfide with peroxynitrite and other oxidants of biological interest / M. Carballal, E. Trujillo, S. Cuevasanta et al. // Free Rad. Biol. Med. - 2011. - Vol. 50, Issue 1, P. 196-205. doi: 10.1016/j.freeradbiomed.2010.10.705

29. Zhao, Y. Cysteine-Activated Hydrogen Sulfide (H2S) Donors / Y. Zhao, H. Wang, M. J. Xian // Am. Chem. Soc. - 2011. - Vol. 133, Issue 1. - P. 15-17. doi: $10.1021 / \mathrm{ja} 1085723$

30. Wang, R. Two's company, three's a crowd : can H2S be the third endogenous gaseous transmitter? / R. Wang // FASEB J. - 2002. - Vol. 16 , Issue 13. - P. 1792-1798. doi: 10.1096/fj.02-0211hyp

31. The vasorelaxant effect of H2S as a novel endogenous gaseous KATP channel opener / W. Zhao, J. Zhang, Y. Lu, R. Wang // EMBO J. - 2001. - Vol. 20, Issue 21. - P. 6008-6016. doi: 10.1093/emboj/20.21.6008

32. Tang, G. Direct stimulation of KATP channels by exogenous and endogenous hydrogen sulfide in vascular smooth muscle / G. Tang // Mol. Pharmacol. -2005. - Vol. 68. - P. 1757-1764. doi: 10.1124/mol.105.017467 
33. Zhao, W. H2S-induced vasorelaxation and underlying cellular and molecular mechanisms / W. Zhao, R. Wang // Am. J. Physiol. Heart Circ. Physiol. - 2002. - Vol. 283, Issue 2. - P. H474-H480. doi: 10.1152/ajpheart.00013.2002

34. Hydrogen sulfide in combination with taurine or cysteic acid reversibly abolishes sodium currents in neuroblastoma cells / M. W. Warenycia, J. A. Steele, E. Karpinski, R. J. Reiffenstein // Neurotox. - 1989. - Vol. 10. - P. 191-199.

35. Biomarkers of oxidative and nitro-oxidative stress: conventional and novel approaches / A. Cipak Gasparovic, N. Zarkovic, K. Zarkovic et al. // Brit. J. Pharmacol. - 2017. doi: 10.1111/bph.13673

36. Vasoconstrictive effect of hydrogen sulfide involves downregulation of cAMP in vascular smooth muscle cells / J. J. Lim, Y.-H. Liu et al. // Am. J. Physiol. Cell Physiol. - 2008. - Vol. 295, Issue 5. - P. C1261-C1270. doi: 10.1152/ajpcell.00195.2008

37. Hydrogen Sulfide-Induced Dual Vascular Effect Involves Arachidonic Acid Cascade in Rat Mesenteric Arterial Bed / R. d'E. Di Villa Bianca, R. Sorrentino, C. Coletta et al. // J. Pharmacol. Exp. Ther. - 2011. -Vol. 337, Issue 1. - P. 59-64. doi: 10.1124/jpet.110.176016

38. The Role of Endogenous H2S in Cardiovascular Physiology / N. Skovgaard, A. Gouliaev, M. Aalling, U. Simonsen // Curr. Pharm. Biotechnol. - 2011. - Vol. 12, Issue 9. - P. 1385-1393. doi: 10.2174/138920111798280956

39. Contractile and Vasorelaxant Effects of Hydrogen Sulfide and Its Biosynthesis in the Human Internal Mammary Artery / G. D. Webb, L. H. Lim, V. M. S. Oh et al. // J. Pharmacol. Exp. Ther. - 2008. - Vol. 324, Issue 2. - P. 876-882. doi: 10.1124/jpet.107.133538

40. Lavu, M. Hydrogen sulfide-mediated cardioprotection : mechanisms and therapeutic potential / M. Lavu, S. Bhushan, D. J. Lefler // Clin. Sci. 2011. - Vol. 120, Issue 6. - P. 219-229. doi: 10.1042/CS20100462

41. Brittain, T. The interaction of human neuroglobin with hydrogen sulphide / T. Brittain, Y. Yosaatmadja, K. Henty // IUBMB Life. - 2008. - Vol. 60, Issue 2. - P. 135-138.doi: 10.1002/iub.16

42. Hydrogen sulfide mitigates matrix metalloproteinase- 9 activity and neurovascular permeability in hyperhomocysteinemic mice / N. Tyagi, S. Givvimani, N. Qipshidze et al. // Neurochem. Int. - 2010. - Vol. 56, Issue 2. - P. 301-307. doi: 10.1016/j.neuint.2009.11.002

43. Calvert, J. W. Novel Insights Into Hydrogen Sulfide-Mediated Cytoprotection / J. W. Calvert, W. A. Coetzee, D. J. Lefer //Antioxid. Redox. Signal. 2010. - Vol. 12, Issue 10. - P. 1203-1217. doi: 10.1089/ars.2009.2882

44. Physiological and pharmacological features of the novel gasotransmitter : Hydrogen sulfide / D. Mancardi, C. Penna, A. Merlino et al. // Biochim. Biophys. Acta. - 2009. - Vol. 1787, Issue 7. - P. 864-872. doi: 10.1016/j.bbabio.2009.03.005

45. Whiteman, M. Hydrogen sulfide and the vasculature: a novel vasculoprotective entity and regulator of nitric oxide bioavailability? / M. Whiteman, P. K. Moore // J. Cell Mol. Med. - 2009. - Vol. 13, Issue 3. - P. 488-507. doi: 10.1111/j.1582-4934.2009.00645.x

46. Chemical probes for molecular imaging and detection of hydrogen sulfide and reactive sulfur species in biological systems / V. S. Lin, W. Chen, M. Xian, C. J. Chang // Chemical. Soc. Rev. - 2015. - Vol. 44, Issue 14. - P. 4596-4618. doi: 10.1039/C4CS00298A

47. Юрченко, П. О. Роль системи гідроген сульфіду в механізмах ураження мозку за умов гіпергомоцистеїнемії : дис. ... н. ст. канд. мед. наук : 14.01.32 / П. О. Юрченко. - Вінниця, 2016.

48. Пентюк, Н. О. Гіперпродукція вазоактивних медіаторів як патогенетичний чинник розвитку ускладнень цирозу печінки у щурів / Н. О. Пентюк, Н. В. Харченко // Сучасна гастроентерол. - 2010. - № 2 (52), C. 33-43. Режим доступу : http://vitapol.com.ua/user_files/ pdfs/gastro/978639636524872_06062010115352.pdf

49. Li, L. Could hydrogen sulfide be the next blockbuster treatment for inflammatory disease? / L. Li, P. K. Moore // Expert. Rev. Clin. Pharmacol. 2013. - Vol. 6, Issue 6. - P. 593-595. doi: 10.1586/17512433.2013.842126

50. Wallace, J. L. Hydrogen sulfide-releasing anti-inflammatory drugs / J. L. Wallace // Trends Pharmacol. Sci. - 2007. - Vol. 28, Issue 10. - P. 501-505. doi: 10.1016/j.tips.2007.09.003

51. Hydrogen sulfide induces ICAM-1 expression and neutrophil adhesion to caerulein-treated pancreatic acinar cells through NF- $\mathrm{B}$ and Src-family kinases pathway / R. Tamizhselvi, Y. H. Koh, J. Sun et al. // Exp. Cell Res. - 2010. - Vol. 316, Issue 9. - P. 1625-1636. doi: 10.1016/j.yexcr.2010.02.044

52. Pro-inflammatory effects of hydrogen sulphide on substance P in caerulein-induced acute pancreatitis / M. Bhatia, J. N. Sidhapuriwala et al. // J. Cell Mol. Med. - 2008. - Vol. 12, Issue 2. - P. 580-590. doi: 10.1111/j.1582-4934.2007.00131.x

53. Hydrogen sulfide donors in research and drug development / Z. J. Song, M. Y. Ng, Z. W. Lee et al. // Med. Chem. Comm. - 2014. - Vol. 5, Issue 5. 557 p. doi: 10.1039/C3MD00362K

54. Forgan, L. G. Oxygen consumption, ventilation frequency and cytochrome c oxidase activity in blue cod (Parapercis colias) exposed to hydrogen sulphide or isoeugenol / L. G. Forgan, M. E. Forster // Comp. Biochem. Physiol. Toxicol. Pharmacol : CBP. - 2010. - Vol. 151, Issue 1. - P. 57-65. doi: 10.1016/j.cbpc.2009.08.008

55. Baumgart, K. Applying gases for microcirculatory and cellular oxygenation in sepsis : effects of nitric oxide, carbon monoxide, and hydrogen sulfide / K. Baumgart, P. Radermacher, F. Wagner // Curr. Opin. Anaesthesiol. - 2009. - Vol. 22, Issue 2. - P. 168-176. doi: 10.1097/AC0.0b013e328328d22f

56. H2S during circulatory shock : Some unresolved questions / O. McCook, P. Radermacher, C. Volani et al. // Nitric Oxide. - 2014. - Vol. 41, P. 48-61. doi: 10.1016/j.niox.2014.03.163

57. Hartle, M. D. A practical guide to working with H2S at the interface of chemistry and biology / M. D. Hartle, M. D. Pluth // Chem. Soc. Rev. - 2016. - Vol. 45, Issue 2. - P. 6108-6117. doi: 10.1039/C6CS00212A

58. Wallace, J. L. Hydrogen sulfide-based therapeutics: exploiting a unique but ubiquitous gasotransmitter / J. L. Wallace, R. Wang // Nat. Rev. Drug Discov. -2015. - Vol. 14, Issue 5. - P. 329-345. doi: 10.1038/nrd4433

59. Onions? A global benefit to health / G. Griffiths, L. Trueman et al. // Phytother. Res. - 2002. - Vol. 16, Issue 7. - P. 603-615. doi: 10.1002/ptr.1222

60. Смаглий, Л. Сероводород - новое лекарство для сосудов / Л. Смаглий // Биомолекула. - 2013. Режим доступа : http://biomolecula.ru/ content/1373.

61. Synthesis and Biological Effects of Hydrogen Sulfide (H2S) : Development of H2S-Releasing Drugs as Pharmaceuticals / G. Caliendo, G. Cirino, V. Santagada, J. L. Wallace // J. Med. Chem. - 2010. - Vol. 53, Issue 17. - P. 6275-6286. doi: 10.1021/jm901638j

62. Phosphinodithioate and Phosphoramidodithioate Hydrogen Sulfide Donors / M. Whiteman, A. Perry, Z. Zhou et al. // Handbook of Exp. Pharmacol. - 2015. - Vol. 230. - P. 337-363. doi: 10.1007/978-3-319-18144-8_17

63. Characterization of a Novel, Water-Soluble Hydrogen Sulfide-Releasing Molecule (GYY4137) : New Insights Into the Biology of Hydrogen Sulfide / L. Li, M. Whiteman, Y. Y. Guan et al. // Circulation. - 2008. - Vol. 117, Issue 18. - P. 2351-2360. doi: 10.1161/CIRCULATIONAHA.107.753467

64. The Slow-Releasing Hydrogen Sulfide Donor, GYY4137, Exhibits Novel Anti-Cancer Effects In Vitro and In Vivo / Z. W. Lee, J. Zhou et al. // PLoS One. - 2011. - Vol. 6, Issue 6. - e21077 p. doi: 10.1371/journal.pone.0021077

65. Synthesis and evaluation of phosphorodithioate-based hydrogen sulfide donors / C. Park, Y. Zhao, Z. Zhu et al. // Mol. Bio. Syst. - 2013. - Vol. 9, Issue 10. -P. 2430-2434. doi: 10.1039/C3MB70145J

66. Kodela, R. NOSH-Aspirin : A Novel Nitric Oxide-Hydrogen Sulfide-Releasing Hybrid: A New Class of Anti-inflammatory Pharmaceuticals / R. Kodela, M. Chattopadhyay, K. Khosrow // ACS Med. Chem. Lett. - 2012. - Vol. 3, Issue 3. - P. 257-262. doi: 10.1021/ml300002m

67. Enhanced chemopreventive effects of a hydrogen sulfide-releasing anti-inflammatory drug (ATB-346) in experimental colorectal cancer / W. Elsheikh, R. W. Blackler, K. L. Flannigan, J. L. Wallace // Nitric Oxide. - 2014. - Vol. 41. - P.131-137. doi: 10.1016/j.niox.2014.04.006

68. Thioglycine and l-thiovaline : Biologically active H2S-donors / Z. Zhou, M. von Wantoch Rekowski, C. Coletta, C. Szabo et al. // Bioorg. Med. Chem. - 2012. - Vol. 20, Issue 8. - P. 2675-2678. doi: 10.1016/j.bmc.2012.02.028 
69. Light-Induced Hydrogen Sulfide Release from “Caged” gem-Dithiols / N. O. Devarie-Baez, P. E. Bagdon, B. Peng et al. // Org. Lett. - 2013. - Vol. 15, Issue 11. - P. 2786-2789. doi: 10.1021/ol401118k

70. New Biologically Active Hydrogen Sulfide Donors / T. Roger, F. Raynaud et al. // ChemBioChem. - 2013. - Vol. 14, Issue 17. - P. 2268-2271. doi: $10.1002 /$ cbic. 201300552

71. Synthesis of a photocontrollable hydrogen sulfide donor using ketoprofenate photocages / N. Fukushima, N. Ieda et al. // Chem. Commun. - 2014. - Vol. 50, Issue 5. - P. 587-589. doi: 10.1039/C3CC47421F

72. Anti-inflammatory and gastrointestinal effects of a novel diclofenac derivative / L. Li, G. Rossoni et al. // Free Rad. Biol. Med. - 2007. - Vol. 42, Issue 5. - P. 706-719. doi: 10.1016/j.freeradbiomed.2006.12.011

73. Hydrogen Sulfide Releasing Aspirin, ACS14, Attenuates High Glucose-Induced Increased Methylglyoxal and Oxidative Stress in Cultured Vascular Smooth Muscle Cells / Q. Huang, A. Sparatore, P. Del Soldato et al. // PloS ONE. - 2014. - Vol. 9, Issue 6. - e97315 p. doi: 10.1371/journal. pone.0097315

74. NOSH-aspirin (NBS-1120), a novel nitric oxide- and hydrogen sulfide-releasing hybrid is a potent inhibitor of colon cancer cell growth in vitro and in a xenograft mouse model / M. Chattopadhyay, R. Kodela, K. R., Olson, K. Kashfi // Biochem. Biophys. Res. Commun. - 2012. - Vol. 419, Issue 3. - P. 523-528. doi: 10.1016/j.bbrc.2012.02.051

75. Elsey, D. J. Regulation of cardiovascular cell function by hydrogen sulfide (H2S) / D. J. Elsey, R. C. Fowkes, G. F. Baxter // Cell Biochem. Func. - 2010. Vol. 28, Issue 2. - P. 95-106. doi: 10.1002/cbf.1618

76. Hydrogen sulfide attenuates neurodegeneration and neurovascular dysfunction induced by intracerebral-administered homocysteine in mice / P. K. Kamat, A. Kalani, S. Givvimani et al. // Neurosci. - 2013. - Vol. 252. - P. 302-319. doi: 10.1016/j.neuroscience.2013.07.051

77. Aruoma, O. I. Protection Against Oxidative Damage and Cell Death by the Natural Antioxidant Ergothioneine / O. I. Aruoma, J. P. E. Spencer, N. Mahmood // Food Chem. Toxicol. - 1999. - Vol. 37, Issue 11. - P. 1043-1053. doi: 10.1016/S0278-6915(99)00098-8

78. Mitsuyama, H. Uptake and antioxidant effects of ergothioneine in human erythrocytes / H. Mitsuyama, J. M. May // Clin. Sci. - 1999. - Vol. 97, Issue 4. - P. 407-411. doi: 10.1042/cs0970407

79. Lesyk, R. B. 4-Thiazolidones : Centenarian History, Current Status and Perspectives for Modern Organic and Medicinal Chemistry / R. B. Lesyk, B. S. Zimenkovsky // Curr. Org. Chem. - 2004. - Vol. 8, Issue 16. - P. 1547-1577. doi: 10.2174/1385272043369773

80. Пат. України на корисну модель G 09 В 23/28. Спосіб зниження ульцерогенної дії нестероїдних протизапальних препаратів на експериментальних моделях у щурів / Ільків, І. І., Лесик, Р. Б., Скляров, О. Я. - 108412 ; опубл. 11.07.2016, Бюл. № 13.

81. Ilkiv, I. Evaluation of novel 4-thiazolidinone-based derivatives as possible cytoprotective agents against stress model in rats / I. Ilkiv, R. Lesyk, 0. J. Sklyarov // Appl. Pharm. Sci. - 2017. - Vol. 7, Issue 01. - P. 199-203. doi: 10.7324/JAPS.2017.70129

\section{References}

1. Lowicka, E., Beltowski, J. (2007). Hydrogen sulfide (H(2)S) - the third gas of interest for pharmacologists. Pharmacol. Reports, 59 (1), 4-24. Available at: http://if-pan.krakow.pl/pjp/pdf/2007/1_4.pdf

2. Li, L., Hsu, A., Moore, P. K. (2009). Actions and interactions of nitric oxide, carbon monoxide and hydrogen sulphide in the cardiovascular system and in inflammation - a tale of three gases! Pharmacol. \& Therapeutics, 123 (3), 386-400. doi: 10.1016/j.pharmthera.2009.05.005

3. Pryor, W. A. (2006). Free radical biology and medicine: it's a gas, man! AJP: Regulatory, Integrative and Comparative Physiology, 291 (3), R491-R511. doi: 10.1152/ajpregu.00614.2005

4. Abe, K., Kimura, H. J. (1996). The possible role of hydrogen sulfide as an endogenous neuromodulator. Neuroscience, 16 (3), 1066-1071. Available at: http://www.jneurosci.org/content/jneuro/16/3/1066.full.pdf

5. Brosnan, J. T., Brosnan, M. E. (2006). The sulfur-containing amino acids: an overview. J. Nutrit., 136 (6), 1636-1640. Available at: http:// jn.nutrition.org/content/136/6/1636S.full.pdf+html

6. Durand, P., Prost, M., Loreau, N., Lussier-Cacan, S. D. (2001). Blache Impaired homocysteine metabolism and atherothrombotic disease. D. Lab. Invest, 81 (5), 645-672. Available at: http://www.nature.com/labinvest/journal/v81/n5/pdf/3780275a.pdf

7. Hayes, K. C., Sturman, J. A. (1981). Taurine in metabolism. Ann. Rev. Nutr., 1, 401-425.

8. Kabil, O., Banerjee, R. (2014). Enzymology of H2S Biogenesis, Decay and Signaling. Antioxidants \& Redox Signaling, 20 (5), 770-782. doi: 10.1089/ ars.2013.5339

9. Kimura, H. (2011). Hydrogen sulfide: its production and functions. Experimental Physiology, 96 (9), 833-835. doi: 10.1113/expphysiol.2011.057455

10. Kimura, H. (2013). Physiological role of hydrogen sulfide and polysulfide in the central nervous system. Neurochem. Int., 63 (5), 492-497. doi: 10.1016/j.neuint.2013.09.003

11. Zhang, M., Shan, H., Wang, T., Liu, W., Wang, Y., Wang, L., Tao, L. (2013). Dynamic Change of Hydrogen Sulfide After Traumatic Brain Injury and its Effect in Mice. Neurochemical Research, 38 (4), 714-725. doi: 10.1007/s11064-013-0969-4

12. Shibuya, N., Mikami, Y., Kimura, Y., Nagahara, N., Kimura, H. (2009). Vascular Endothelium Expresses 3-Mercaptopyruvate Sulfurtransferase and Produces Hydrogen Sulfide. Journal of Biochemistry, 146 (5), 623-626. doi: 10.1093/jb/mvp111

13. Wang, R. (2012). Physiological Implications of Hydrogen Sulfide: A Whiff Exploration That Blossomed. Physiological Reviews, 92 (2), $791-896$. doi: 10.1152/physrev.00017.2011

14. Shibuya, N., Koike, S., Tanaka, M., Ishigami-Yuasa, M., Kimura, Y., Ogasawara, Y., Kimura, H. (2013). A novel pathway for the production of hydrogen sulfide from D-cysteine in mammalian cells. Nature Communications, 4, 1366. doi: 10.1038/ncomms2371

15. Jakubowski, H., Goldman, E. (1993). Synthesis of homocysteine thiolactone by methionyl-tRNA synthetase in cultured mammalian cells. FEBS Letters, 317 (3), 237-240. doi: 10.1016/0014-5793(93)81283-6

16. Eto, K., Kimura, H. (2002). The production of hydrogen sulfide is regulated by testosterone and S-adenosyl-l-methionine in mouse brain. Journal of Neurochemistry, 83 (1), 80-86. doi: 10.1046/j.1471-4159.2002.01097.x

17. Obeid, R., Herrmann, W. (2006). Mechanisms of homocysteine neurotoxicity in neurodegenerative diseases with special reference to dementia. FEBS Letters, 580 (13), 2994-3005. doi: 10.1016/j.febslet.2006.04.088

18. Kimura, H., Shibuya, N., Kimura, Y. (2012). Hydrogen Sulfide Is a Signaling Molecule and a Cytoprotectant. Antioxidants \& Redox Signaling, 17 (1), 45-57. doi: 10.1089/ars.2011.4345

19. Mikami, Y., Shibuya, N., Kimura, Y., Nagahara, N., Ogasawara, Y., Kimura, H. (2011). Thioredoxin and dihydrolipoic acid are required for 3-mercaptopyruvate sulfurtransferase to produce hydrogen sulfide. Biochemical Journal, 439 (3), 479-485. doi: 10.1042/bj20110841

20. Li, Q., Lancaster, J. R. (2013). Chemical foundations of hydrogen sulfide biology. Nitric Oxide, 35, 21-34. doi: 10.1016/j.niox.2013.07.001

21. Zhao, Y., Biggs, T. D., Xian, M. (2014). Hydrogen sulfide (H2S) releasing agents: chemistry and biological applications. Chem. Commun., 50 (80), 11788-11805. doi: 10.1039/c4cc00968a

22. Pluth, M., Bailey, T., Hammers, M., Hartle, M., Henthorn, H., Steiger, A. (2015). Natural Products Containing Hydrogen Sulfide Releasing Moieties. Synlett, 26 (19), 2633-2643. doi: 10.1055/s-0035-1560638

23. Kimura, Y., Mikami, Y., Osumi, K., Tsugane, M., Oka, J. -I., Kimura, H. (2013). Polysulfides are possible H2S-derived signaling molecules in rat brain. The FASEB Journal, 27 (6), 2451-2457. doi: 10.1096/fj.12-226415 
24. Kimura, H. (2010). Hydrogen sulfide: its production, release and functions. Amino Acids, 41 (1), 113-121. doi: 10.1007/s00726-010-0510-X

25. Hughes, M. N., Centelles, M. N., Moore, K. P. (2009). Making and working with hydrogen sulfide. Free Radical Biology and Medicine, 47 (10), $1346-1353$. doi: 10.1016/j.freeradbiomed.2009.09.018

26. Guo, W., Cheng, Z., Zhu, Y. (2013). Hydrogen sulfide and translational medicine. Acta Pharmacologica Sinica, 34 (10), 1284-1291. doi: 10.1038/ aps.2013.127

27. Kashfi, K., Olson, K. R. (2013). Biology and therapeutic potential of hydrogen sulfide and hydrogen sulfide-releasing chimeras. Biochemical Pharmacology, 85 (5), 689-703. doi: 10.1016/j.bcp.2012.10.019

28. Carballal, S., Trujillo, M., Cuevasanta, E., Bartesaghi, S., Möller, M. N., Folkes, L. K., Alvarez, B. (2011). Reactivity of hydrogen sulfide with peroxynitrite and other oxidants of biological interest. Free Radical Biology and Medicine, 50 (1), 196-205. doi: 10.1016/j.freeradbiomed.2010.10.705

29. Zhao, Y., Wang, H., Xian, M. (2011). Cysteine-Activated Hydrogen Sulfide (H2S) Donors. Journal of the American Chemical Society, 133 (1), $15-17$. doi: $10.1021 /$ ja1085723

30. Wang, R. (2002). Two's company, three's a crowd: can H2S be the third endogenous gaseous transmitter? FASEB J., 16 (13), 1792-1798. doi: 10.1096/fj.02-0211hyp

31. Zhao, W. (2001). The vasorelaxant effect of H2S as a novel endogenous gaseous KATP channel opener. The EMBO Journal, 20 (21), $6008-6016$. doi: $10.1093 /$ emboj/20.21.6008

32. Tang, G. (2005). Direct stimulation of KATP channels by exogenous and endogenous hydrogen sulfide in vascular smooth muscle. Molecular Pharmacology. doi: 10.1124/mol.105.017467

33. Zhao, W., Wang, R. (2002). H2S-induced vasorelaxation and underlying cellular and molecular mechanisms. American Journal of Physiology Heart and Circulatory Physiology, 283 (2), H474-H480. doi: 10.1152/ajpheart.00013.2002

34. Warenycia, M. W., Steele, J. A., Karpinski, E., Reiffenstein, R. J. (1989). Hydrogen sulfide in combination with taurine or cysteic acid reversibly abolishes sodium currents in neuroblastoma cells. Neurotox., 10, 191-199.

35. Cipak Gasparovic, A., Zarkovic, N., Zarkovic, K., Semen, K., Kaminskyy, D., Yelisyeyeva, O., Bottari, S. P. (2017). Biomarkers of oxidative and nitrooxidative stress: conventional and novel approaches. British Journal of Pharmacology. doi: 10.1111/bph.13673

36. Lim, J. J., Liu, Y.-H., Khin, E. S. W., Bian, J.-S. (2008). Vasoconstrictive effect of hydrogen sulfide involves downregulation of cAMP in vascular smooth muscle cells. AJP: Cell Physiology, 295 (5), C1261-C1270. doi: 10.1152/ajpcell.00195.2008

37. D’ Emmanuele di Villa Bianca, R., Sorrentino, R., Coletta, C., Mitidieri, E., Rossi, A., Vellecco, V., Sorrentino, R. (2011). Hydrogen Sulfide-Induced Dual Vascular Effect Involves Arachidonic Acid Cascade in Rat Mesenteric Arterial Bed. Journal of Pharmacology and Experimental Therapeutics, 337 (1), 59-64. doi: 10.1124/jpet.110.176016

38. Skovgaard, N., Gouliaev, A., Aalling, M., Simonsen, U. (2011). The Role of Endogenous H2S in Cardiovascular Physiology. Current Pharmaceutical Biotechnology, 12 (9), 1385-1393. doi: 10.2174/138920111798280956

39. Webb, G. D., Lim, L. H., Oh, V. M. S., Yeo, S. B., Cheong, Y. P., Ali, M. Y., Moore, P. K. (2007). Contractile and Vasorelaxant Effects of Hydrogen Sulfide and Its Biosynthesis in the Human Internal Mammary Artery. Journal of Pharmacology and Experimental Therapeutics, 324 (2), 876-882. doi: 10.1124/jpet.107.133538

40. Lavu, M., Bhushan, S., Lefer, D. J. (2011). Hydrogen sulfide-mediated cardioprotection: mechanisms and therapeutic potential. Clinical Science, 120 (6), 219-229. doi: 10.1042/cs20100462

41. Brittain, T., Yosaatmadja, Y., Henty, K. (2008). The interaction of human neuroglobin with hydrogen sulphide. IUBMB Life, 60 (2), 135-138. doi: 10.1002/iub.16

42. Tyagi, N., Givvimani, S., Qipshidze, N., Kundu, S., Kapoor, S., Vacek, J. C., Tyagi, S. C. (2010). Hydrogen sulfide mitigates matrix metalloproteinase-9 activity and neurovascular permeability in hyperhomocysteinemic mice. Neurochemistry International, 56 (2), 301-307. doi: 10.1016/j.neuint.2009.11.002

43. Calvert, J. W., Coetzee, W. A., Lefer, D. J. (2010). Novel Insights Into Hydrogen Sulfide-Mediated Cytoprotection. Antioxidants \& Redox Signaling, 12 (10), 1203-1217. doi: 10.1089/ars.2009.2882

44. Mancardi, D., Penna, C., Merlino, A., Del Soldato, P., Wink, D. A., Pagliaro, P. (2009). Physiological and pharmacological features of the novel gasotransmitter: Hydrogen sulfide. Biochimica et Biophysica Acta (BBA) - Bioenergetics, 1787 (7), 864-872. doi: 10.1016/j.bbabio.2009.03.005

45. Whiteman, M., Moore, P. K. (2009). Hydrogen sulfide and the vasculature: a novel vasculoprotective entity and regulator of nitric oxide bioavailability? Journal of Cellular and Molecular Medicine, 13 (3), 488-507. doi: 10.1111/j.1582-4934.2009.00645.x

46. Lin, V. S., Chen, W., Xian, M., Chang, C. J. (2015). Chemical probes for molecular imaging and detection of hydrogen sulfide and reactive sulfur species in biological systems. Chem. Soc. Rev., 44 (14), 4596-4618. doi: 10.1039/c4cs00298a

47. Yurchenko, P. O. (2016). Rol systemy hidrohen sulfidu $v$ mekhaniznakh urazhennia mozku za umov hiperhomotsysteinemii. Vinnytsia

48. Pentiuk, N. O. (2010). Suchasna gastroenterolohiia, 2 (52), 33-43. Available at: http://vitapol.com.ua/user_files/pdfs/gastro/978639636524872_ 060620101 5352.pdf

49. Li, L., Moore, P. K. (2013). Could hydrogen sulfide be the next blockbuster treatment for inflammatory disease? Expert Review of Clinical Pharmacology, 6 (6), 593-595. doi: 10.1586/17512433.2013.842126

50. Wallace, J. L. (2007). Hydrogen sulfide-releasing anti-inflammatory drugs. Trends in Pharmacological Sciences, 28 (10), 501-505. doi: 10.1016/j. tips.2007.09.003

51. Tamizhselvi, R., Koh, Y.-H., Sun, J., Zhang, H., Bhatia, M. (2010). Hydrogen sulfide induces ICAM-1 expression and neutrophil adhesion to caeruleintreated pancreatic acinar cells through $\mathrm{NF}-\mathrm{\kappa B}$ and Src-family kinases pathway. Experimental Cell Research, 316 (9), 1625-1636. doi: 10.1016/j. yexcr.2010.02.044

52. Bhatia, M., Sidhapuriwala, J. N., Wei Ng, S., Tamizhselvi, R., Moochhala, S. M. (2008). Pro-inflammatory effects of hydrogen sulphide on substance $P$ in caerulein-induced acute pancreatitis. Journal of Cellular and Molecular Medicine, 12 (2), 580-590. doi: 10.1111/j.1582-4934.2007.00131.x

53. Song, Z. J., Ng, M. Y., Lee, Z.-W., Dai, W., Hagen, T., Moore, P. K., Tan, C.-H. (2014). Hydrogen sulfide donors in research and drug development. MedChemComm, 5 (5), 557. doi: 10.1039/c3md00362k

54. Forgan, L. G., Forster, M. E. (2010). Oxygen consumption, ventilation frequency and cytochrome c oxidase activity in blue cod (Parapercis colias) exposed to hydrogen sulphide or isoeugenol. Comparative Biochemistry and Physiology Part C: Toxicology \& Pharmacology, 151 (1), 57-65. doi: 10.1016/j.cbpc.2009.08.008

55. Baumgart, K., Radermacher, P., Wagner, F. (2009). Applying gases for microcirculatory and cellular oxygenation in sepsis: effects of nitric oxide, carbon monoxide, and hydrogen sulfide. Current Opinion in Anaesthesiology, 22 (2), 168-176. doi: 10.1097/aco.0b013e328328d22f

56. McCook, O., Radermacher, P., Volani, C., Asfar, P., Ignatius, A., Kemmler, J., Wachter, U. (2014). H2S during circulatory shock: Some unresolved questions. Nitric Oxide, 41,48-61. doi: 10.1016/j.niox.2014.03.163

57. Hartle, M. D., Pluth, M. D. (2016). A practical guide to working with H2S at the interface of chemistry and biology. Chem. Soc. Rev., 45 (22), 6108-6117. doi: $10.1039 / \mathrm{c} 6 \mathrm{cs} 00212 \mathrm{a}$

58. Wallace, J. L., Wang, R. (2015). Hydrogen sulfide-based therapeutics: exploiting a unique but ubiquitous gasotransmitter. Nature Reviews Drug Discovery, 14 (5), 329-345. doi: 10.1038/nrd4433

59. Griffiths, G., Trueman, L., Crowther, T., Thomas, B., Smith, B. (2002). Onions? A global benefit to health. Phytotherapy Research, 16 (7), $603-615$. doi: $10.1002 /$ ptr.1222 
60. Smaglii, L. (2013). Biomolekula. Available at: http://biomolecula.ru/content/1373.

61. Caliendo, G., Cirino, G., Santagada, V., Wallace, J. L. (2010). Synthesis and Biological Effects of Hydrogen Sulfide (H2S): Development of H2S-Releasing Drugs as Pharmaceuticals. Journal of Medicinal Chemistry, 53 (17), 6275-6286. doi: 10.1021/jm901638j

62. Whiteman, M., Perry, A., Zhou, Z., Bucci, M., Papapetropoulos, A., Cirino, G., Wood, M. E. (2015). Phosphinodithioate and Phosphoramidodithioate Hydrogen Sulfide Donors. Handbook of Experimental Pharmacology, 337-363. doi:10.1007/978-3-319-18144-8_17

63. Li, L., Whiteman, M., Guan, Y. Y., Neo, K. L., Cheng, Y., Lee, S. W., Moore, P. K. (2008). Characterization of a Novel, Water-Soluble Hydrogen SulfideReleasing Molecule (GYY4137): New Insights Into the Biology of Hydrogen Sulfide. Circulation, 117 (18), 2351-2360. doi: 10.1161/circulationaha.107.753467

64. Lee, Z. W., Zhou, J., Chen, C.-S., Zhao, Y., Tan, C.-H., Li, L., Deng, L.-W. (2011). The Slow-Releasing Hydrogen Sulfide Donor, GYY4137, Exhibits Novel Anti-Cancer Effects In Vitro and In Vivo. PLOS ONE, 6 (6), e21077. doi: 10.1371/journal.pone.0021077

65. Park, C.-M., Zhao, Y., Zhu, Z., Pacheco, A., Peng, B., Devarie-Baez, N. O., Xian, M. (2013). Synthesis and evaluation of phosphorodithioate-based hydrogen sulfide donors. Molecular BioSystems, 9 (10), 2430. doi: 10.1039/c3mb70145j

66. Kodela, R., Chattopadhyay, M., Kashfi, K. (2012). NOSH-Aspirin: A Novel Nitric Oxide-Hydrogen Sulfide-Releasing Hybrid: A New Class of Antiinflammatory Pharmaceuticals. ACS Medicinal Chemistry Letters, 3 (3), 257-262. doi: 10.1021/ml300002m

67. Elsheikh, W., Blackler, R. W., Flannigan, K. L., Wallace, J. L. (2014). Enhanced chemopreventive effects of a hydrogen sulfide-releasing anti-inflammatory drug (ATB-346) in experimental colorectal cancer. Nitric Oxide, 41, 131-137. doi: 10.1016/j.niox.2014.04.006

68. Zhou, Z., von Wantoch Rekowski, M., Coletta, C., Szabo, C., Bucci, M., Cirino, G., Giannis, A. (2012). Thioglycine and l-thiovaline: Biologically active H2S-donors. Bioorganic \& Medicinal Chemistry, 20 (8), 2675-2678. doi: 10.1016/j.bmc.2012.02.028

69. Devarie-Baez, N. O., Bagdon, P. E., Peng, B., Zhao, Y., Park, C.-M., Xian, M. (2013). Light-Induced Hydrogen Sulfide Release from "Caged" gemDithiols. Organic Letters, 15 (11), 2786-2789. doi: 10.1021/ol401118k

70. Roger, T., Raynaud, F., Bouillaud, F., Ransy, C., Simonet, S., Crespo, C., Galardon, E. (2013). New Biologically Active Hydrogen Sulfide Donors. ChemBioChem, 14 (17), 2268-2271. doi: 10.1002/cbic.201300552

71. Fukushima, N., Ieda, N., Sasakura, K., Nagano, T., Hanaoka, K., Suzuki, T., Nakagawa, H. (2014). Synthesis of a photocontrollable hydrogen sulfide donor using ketoprofenate photocages. Chem. Commun., 50 (5), 587-589. doi: 10.1039/c3cc47421f

72. Li, L., Rossoni, G., Sparatore, A., Lee, L. C., Del Soldato, P., Moore, P. K. (2007). Anti-inflammatory and gastrointestinal effects of a novel diclofenac derivative. Free Radical Biology and Medicine, 42 (5), 706-719. doi: 10.1016/j.freeradbiomed.2006.12.011

73. Huang, Q., Sparatore, A., Del Soldato, P., Wu, L., Desai, K. (2014). Hydrogen Sulfide Releasing Aspirin, ACS14, Attenuates High Glucose-Induced Increased Methylglyoxal and Oxidative Stress in Cultured Vascular Smooth Muscle Cells. PLoS ONE, 9 (6), e97315. doi: 10.1371/journal.pone.0097315

74. Chattopadhyay, M., Kodela, R., Olson, K. R., Kashfi, K. (2012). NOSH-aspirin (NBS-1120), a novel nitric oxide- and hydrogen sulfide-releasing hybrid is a potent inhibitor of colon cancer cell growth in vitro and in a xenograft mouse model. Biochemical and Biophysical Research Communications, 419 (3), 523-528. doi: 10.1016/j.bbrc.2012.02.051

75. Elsey, D. J., Fowkes, R. C., Baxter, G. F. (2010). Regulation of cardiovascular cell function by hydrogen sulfide (H2S). Cell Biochemistry and Function, 28 (2), 95-106. doi: 10.1002/cbf.1618

76. Kamat, P. K., Kalani, A., Givvimani, S., Sathnur, P. B., Tyagi, S. C., Tyagi, N. (2013). Hydrogen sulfide attenuates neurodegeneration and neurovascular dysfunction induced by intracerebral-administered homocysteine in mice. Neuroscience, 252, 302-319. doi: 10.1016/j.neuroscience.2013.07.051

77. Aruoma, O., Spencer, J. P., Mahmood, N. (1999). Protection Against Oxidative Damage and Cell Death by the Natural Antioxidant Ergothioneine. Food and Chemical Toxicology, 37 (11), 1043-1053. doi: 10.1016/s0278-6915(99)00098-8

78. Mitsuyama, H., May, J. M. (1999). Uptake and antioxidant effects of ergothioneine in human erythrocytes. Clinical Science, 97 (4), 407-411. doi: $10.1042 / \operatorname{cs} 0970407$

79. Lesyk, R., Zimenkovsky, B. (2004). 4-Thiazolidones: Centenarian History, Current Status and Perspectives for Modern Organic and Medicinal Chemistry. Current Organic Chemistry, 8 (16), 1547-1577. doi: 10.2174/1385272043369773

80. Ilkiv, I. I., Lesyk, R. B., Skliarov, O. Ya. (2016). Sposib znyzhennia ultserohennoi dii nesteroidnykh protyzapalnykh preparativ na eksperymentalnykh modeliakh u shchuriv. Patent of Ukraine for useful model. G09B 23/28 /. №108412; published 11.07.2016, №3.

81. Ilkiv, I., Lesyk, R., Sklyarov, O. (2017). Evaluation of novel 4-thiazolidinone-based derivatives as possible cytoprotective agents against stress model in rats. Journal of Applied Pharmaceutical Science, 199-203. doi: 10.7324/japs.2017.70129 